\title{
Consequences of artificial deepwater ventilation in the Bornholm Basin for oxygen conditions, cod reproduction and benthic biomass - a model study
}

\author{
A. Stigebrandt ${ }^{1}$, R. Rosenberg $^{2}$, L. Råman Vinnå ${ }^{3}$, and M. Ödalen ${ }^{4}$ \\ ${ }^{1}$ Dept. of Earth Sciences, University of Gothenburg, Gothenburg, Sweden \\ ${ }^{2}$ Dept. of Biological and Environmental Sciences - Kristineberg, University of Gothenburg, \\ Kristineberg Fiskebäckskil, Sweden \\ ${ }^{3}$ EPFL ENAC IIE APHYS, Lausanne, Switzerland \\ ${ }^{4}$ Dept. of Meteorology, University of Stockholm, Stockholm, Sweden
}

Correspondence to: A. Stigebrandt (anst@gvc.gu.se)

Received: 13 June 2014 - Published in Ocean Sci. Discuss.: 9 July 2014

Revised: 7 December 2014 - Accepted: 12 December 2014 - Published: 21 January 2015

\begin{abstract}
We develop and use a circulation model to estimate hydrographical and ecological changes in the isolated basin water of the Bornholm Basin. By pumping welloxygenated so-called winter water to the greatest depth, where it is forced to mix with the resident water, the rate of deepwater density reduction increases as well as the frequency of intrusions of new oxygen-rich deepwater. We show that pumping $1000 \mathrm{~m}^{3} \mathrm{~s}^{-1}$ should increase the rates of water exchange and oxygen supply by 2.5 and 3 times, respectively. The CRV (cod reproduction volume), the volume of water in the isolated basin meeting the requirements for successful cod reproduction $\left(S>11, \mathrm{O}_{2}>2 \mathrm{~mL} \mathrm{~L}^{-1}\right)$, should every year be greater than $54 \mathrm{~km}^{3}$, which is an immense improvement, since it has been much less in certain years. Anoxic bottoms should no longer occur in the basin, and hypoxic events will become rare. This should permit extensive colonization of fauna on the earlier periodically anoxic bottoms. Increased biomass of benthic fauna should also mean increased food supply to economically valuable demersal fish like cod and flatfish. In addition, re-oxygenation of the sediments should lead to increased phosphorus retention by the sediments.
\end{abstract}

\section{Introduction}

The Baltic Sea is the second largest $\left(373000 \mathrm{~km}^{2}\right)$ brackish water system in the world, with an extensive drainage system that is 4 times larger than the sea surface area. The salinity varies from about 1 in the northern Bothnian Sea to about 17 in the deep basins of the southwestern Baltic. The Baltic is enclosed, with restricted water exchange with the adjacent seas: the Kattegat, the Skagerrak and the North Sea. Since the mid-1900s, large volumes of bottom water below the halocline have lacked oxygen concentrations high enough to support the respiration of aquatic organisms. During the last decade, areas of approximately $50000 \mathrm{~km}^{2}$ (year 2011) of the seabed have been anoxic, and $27000 \mathrm{~km}^{2}$ hypoxic ( $<2 \mathrm{~mL} \mathrm{O}_{2} \mathrm{~L}^{-1}$ ), thus lacking benthic animals (Karlson et al., 2002). The Baltic is the largest sea area with anthropogenically related low oxygen concentrations in the world (Diaz and Rosenberg, 2008) because of increased input of organic matter (Bonsdorff et al., 1997) that has changed the ecosystem properties (Elmgren, 1989; Rosenberg et al., 1990). The increased input of organic matter has been boosted by extensive leakage of phosphorus from anoxic bottoms that has increased the phosphorus content in the water column in spite of a halved external supply of phosphorus since the 1980s (Stigebrandt et al., 2014a). As a consequence, the structure and function of the Baltic ecosystem is affected by two main factors - horizontally by increasing 
salinity from north to south and vertically by decreasing oxygen concentrations by depth.

The annual fish catches increased in the Baltic in the middle of the last century, and the highest landings of cod, the most economically valuable species, peaked around 1990, with about 400000 tons (MacKenzie et al., 2000). Cod is dependent on the deeper bottoms of the Baltic for reproduction and feeding, whereas herring and sprat are pelagic feeders. The cod stocks have declined since 1990 because of overly high fishing pressure and unfavorable spawning conditions. Other factors with a negative impact on the cod are the fact that herring and sprat are predators on egg and larvae, which deters the recovery of the cod stock.

The anoxic and hypoxic water in the deeper parts of the Baltic has great negative consequences for the ecosystem. Few or no animals are present at depths deeper than $70 \mathrm{~m}$, which means that there are vast volumes that are lacking fish and fish food. The reproduction of cod is hampered as the eggs need an oxygen concentration greater than $2 \mathrm{mLL}^{-1}$ and a salinity of at least 11 to be buoyant, but this varies somewhat with egg size and the age of the spawning cod (Hinrichsen et al., 2007; Vallin et al., 1999). Such a high salinity is found in the Bornholm Basin and, east of this basin, only close to the bottom and then frequently associated with toxic hydrogen sulfide, which is produced during anoxia. MacKenzie et al. (2002) summarized the volumes of water in the main cod spawning areas of the eastern Baltic and Bornholm basins where salinity and oxygen conditions could allow successful fertilization and hatching. From the mid-1980s, this was almost non-existent in the Gdansk and Gotland basins, and favorable conditions were only found in the Bornholm Basin.

Defaunated sediments appear laminated, which demonstrates that the biogeochemical processes that occur in oxidized sediments do not occur or are significantly changed (Jonsson et al., 1990). Thus, bioturbation (mixing of sediments) and irrigation (pumping of oxygenated water into the sediment) are lacking in laminated sediments. Lack of benthic animals means reduced nitrification and a reduced capacity to bind phosphorus in the top sediments, which may accelerate eutrophication and occasional blooms of cyanobacteria.

It has been suggested that the eutrophication of the Baltic Proper may be reduced by man-made oxygenation of the deepwater, which should decrease the phosphorus content in the water column, and that oxygenation should be done by pumping down well-oxygenated so-called winter water into the deepwater (Stigebrandt and Gustafsson, 2007). Gustafsson et al. (2008) and Conley et al. (2009b) discuss engineering methods that have been suggested to cure hypoxia in the Baltic Sea. Both papers consider below-halocline ventilation, the method applied in the present paper, to be the only realistic alternative.

Before considering oxygenation of the whole Baltic Proper, it may be wise to first look into oxygenation of a

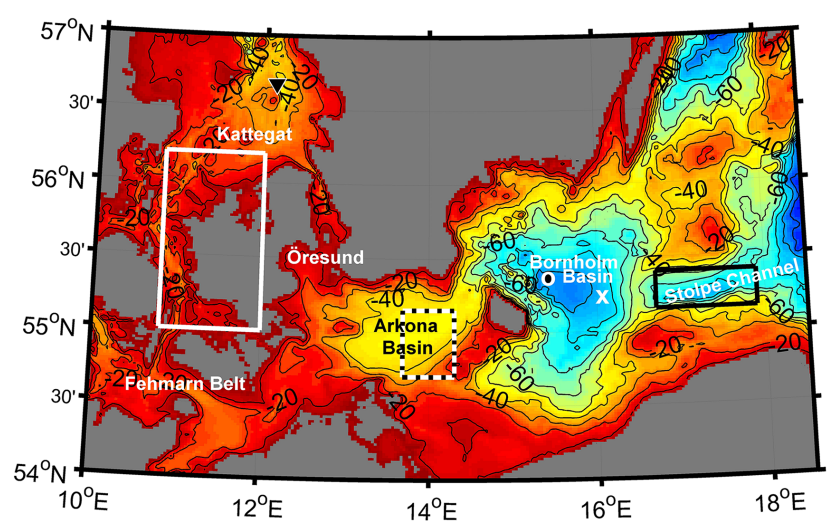

Figure 1. Map of the southern Baltic Sea area (hypsographic data from Seifert et al., 2001). Reference data for the Arkona Basin originate from the area within the white and black dashed rectangle, and reference data stations BY4 and BY5 in the Bornholm Basin are marked by a white o and $\mathrm{x}$, respectively. Data from the Stolpe Channel used for forcing of the model originate from the area within the black rectangle. The forcing data for the freshwater pool model were obtained from within the white rectangle and from the Anholt E station marked by $\mathbf{\nabla}$.

smaller part of the Baltic. In this paper, we have chosen to consider oxygenation of the deepwater of the Bornholm Basin, beneath the level of the greatest depth $(60 \mathrm{~m})$ of the Stolpe Channel (Slupsk Furrow) in the southwestern Baltic Proper (Fig. 1). Very salty deepwater may stay in this basin for several years, whereby hypoxia and anoxia may develop in the lower parts.

Pumping winter water into the deepwater creates a mixture of winter water and deepwater that is buoyant and rises as an entraining plume until it reaches the level where the buoyancy is lost and interleaving occurs. Removal of deepwater by entraining plumes causes a compensatory downward vertical motion to replace the removed water. Pumping thus drives a vertical circulation cell between the levels of interleaving and pump outlet, respectively, with rising motion in the (narrow) buoyant plumes located at the pumps, and sinking motion everywhere outside the plumes. The sinking motion tends to reduce vertical concentration gradients of oxygen and other dissolved substances in the cell.

Stigebrandt and Kalén (2013) implemented pumping in a model of the Bornholm Basin. They showed that pumping $800 \mathrm{~m}^{3} \mathrm{~s}^{-1}$ of winter water from 40 to $90 \mathrm{~m}$ with a tenfold increase in the flow due to mixing at the outlet would have prevented the development of hypoxia and anoxia that occurred during a selected period starting in early May 2003 after a complete water exchange. The characteristics of the modeled pumped flow fit well with observations made in a comprehensive, long-term pilot experiment in the By Fjord, where $2 \mathrm{~m}^{3} \mathrm{~s}^{-1}$ of surface water were pumped into the usually anoxic deepwater (Stigebrandt et al., 2014b). The pumped water had a speed of $2 \mathrm{~m} \mathrm{~s}^{-1}$ through the outlet orifices. The 
total flux of deepwater carried by the plumes at a certain depth can readily be estimated from the speed of vertical migration of isohaline surfaces multiplied by the horizontal surface area of the fjord at that depth. In the By Fjord, the typical downward speed of isohaline surfaces was $2 \mathrm{~m} \mathrm{day}^{-1}$, implying an entrained flow of deepwater that was 30 times greater than the pumped flow. Preliminary estimates suggest a tenfold increase due to initial mixing and a further increase by a factor of 3 due to entrainment in the buoyant plume phase. Furthermore, the pumping in the By Fjord increased the rate of density reduction in the basin water by a factor of 100 and the frequency of water exchanges in the deeper parts of the basin by a factor of 10 (Stigebrandt et al., 2014b).

In the present paper we complement the model in Stigebrandt and Kalén (2013) with a time-dependent model of the inflow of new deepwater into the basin, which allows us to estimate how the rate of water exchange and the oxygen conditions in the deeper parts of the basin would be changed by pumping.

The goal of the present paper is to investigate hydrographical and ecological effects of enhanced deepwater circulation by pumping in the Bornholm Basin. First the pump is turned off (reference run), and the high quality of model predictions is demonstrated by comparisons between model results and hydrographic observations of salinity, temperature and oxygen in the deepwater of the Bornholm Basin for the period 1990-2010 (21 years). Then the pump is turned on to simulate how the vertical circulation of the Bornholm Basin should be affected with regard to residence time and changed salinity, temperature and oxygen conditions. Finally we compute how the changed hydrographical and oxygen conditions should affect the water volume available for successful cod reproduction, and describe the expected colonization of the oxygenated bottoms. We estimate the possible increase in benthic biomass and discuss the importance of this as fish feed and for biogeochemical sediment processes. We also briefly discuss possible effects on the Baltic Sea east of the Bornholm Basin due to changed properties of new deepwater entering from the Bornholm Basin.

\section{Methods}

\subsection{The circulation model}

We will use the vertical advection-diffusion model with high vertical resolution described for the Bornholm Basin by Stigebrandt and Kalén (2013). However, that model lacks a model of the inflow of new deepwater. Here we develop and use a relatively simple mechanistic model of the flow of new deepwater from Kattegat to the Bornholm Basin (for an area map, see Fig. 1). Since the model is used only in the hindcast mode, it may be tuned if necessary to improve the description of the inflow of new deepwater.

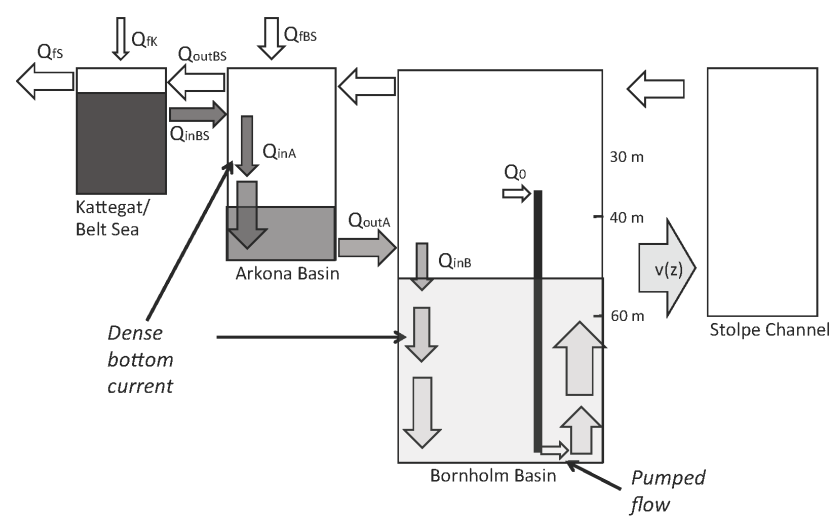

Figure 2. Schematic image of model flows. Grey is used to indicate salinity, with the saltiest water darkest. Dense bottom currents in the Arkona and Bornholm basins are shown by their vertical components. These flows increase with depth due to entrainment of ambient water. Pumping in the Bornholm Basin is shown by a vertical pipe transporting winter water into the deepwater. The pumpinduced flow increases due to initial mixing at the pipe outlet and thereafter by plume mixing while rising. The flows are further described in Sect. 2.1.

A starting point for the construction of our inflow model is the fact that the salinity of the Baltic Sea is controlled essentially by two external factors, namely (i) the freshwater supply to the Baltic Sea and (ii) the sea level variability in Kattegat that drives the water exchange between Kattegat and the Baltic Sea inside the Fehmarn Belt and the Öresund (the Sound) (Stigebrandt, 1983). This implies that the inflow of new deepwater (and salt) to the Baltic Proper is independent of all oceanographic factors inside the entrance area other than the sea level. Freshwater from the Baltic Sea accumulates in the surface layer of the entrance area (Kattegat and the Belt Sea). Due to shallow sills, the presence of this layer partly blocks inflow of seawater from the deeper part of Kattegat to the Baltic, which strongly influences the salinity of new deepwater flowing into the Baltic. However, freshwater from the Baltic Sea is not only re-circulated back to the Baltic with the new deepwater, it is also permanently lost to Skagerrak by a flow that is driven by the excess pressure caused by the accumulated freshwater in the surface layer of Kattegat. Of course, the long-term freshwater export to Skagerrak equals the long-term supply to the whole Baltic Sea, including the entrance area. A schematic image of the model flows (further described below) is shown in Fig. 2.

The daily water exchange between the Baltic Sea and the entrance area is computed from observed changes in the Baltic Sea volume (sea level) and by accounting for freshwater supply inside the entrance area (Sect. 2.1.1). The amount of freshwater in the entrance area, computed by a simple budget model (Sect. 2.1.2), determines the salinity of the new deepwater flowing into the Baltic Sea, which is computed 
using an empirical function by Stigebrandt and Gustafsson (2003) (Sect. 2.1.3).

The inflowing new deepwater moves along the bottom of the Arkona Basin as a dense bottom current that entrains water from above, whereby the volume flow increases and the salinity decreases. The dense bottom current was observed, described and analyzed by Arneborg et al. (2007). This current replenishes the pool of new deepwater in the Arkona Basin. The flow and dynamics of new deepwater in the Arkona Basin are described in Sect. 2.1.4. A current transports water from the deepwater pool towards the Bornholm Basin (Liljebladh and Stigebrandt, 1996; Stigebrandt, 1987a). After having entered the Bornholm Basin, the current of new deepwater is transformed into a dense bottom current, which entrains water from above. When the new deepwater in the bottom current has got the same density as the ambient water, it is interleaved in the Bornholm Basin. Only the densest new deepwater makes it all the way through the halocline and down to the greatest depths; less dense new deepwater is interleaved in the halocline. Water exits the Bornholm Basin through the $59 \mathrm{~m}$ deep Stolpe Channel. For a description of the dynamics of the Bornholm Basin, see Sect. 2.1.5.

\subsubsection{The flow through the entrance straits}

The water exchange through the Öresund and the Fehmarn Belt changes the volume of the Baltic Sea and may thus be quantified from observations of the changing sea level. However, freshwater supply also changes the volume. From conservation of volume, one obtains the following equation for the volume change of the Baltic Sea:

$A_{\mathrm{BS}} \frac{\mathrm{d} h}{\mathrm{~d} t}=Q_{\mathrm{BS}}+Q_{\mathrm{fBS}}$.

Here $\mathrm{d} h / \mathrm{d} t$ is the rate of change of the horizontal average sea level $h, A_{\mathrm{BS}}$ the horizontal surface area of the Baltic Sea, $Q_{\mathrm{fBS}}$ the freshwater supply to the Baltic Sea (inside the entrance area) and $Q_{\mathrm{BS}}$ the water exchange of the Baltic Sea with the entrance area. For use in the model, $Q_{\mathrm{BS}}$ is separated into two parts, $Q_{\text {inBS }}$ and $Q_{\text {outBS }}$, describing inflow and outflow, respectively. The salinity and other properties of these flows are specified in Sect. 2.1.3.

The simple description of the inflowing water is complemented with a low-pass filter removing inflows resulting from high-frequency fluctuations. This is because the first water flowing towards the Baltic Proper after a period of outflow is just surface water from the Baltic. This can be handled by removing certain volumes of the first coming transport, both outgoing and ingoing, using a buffer volume. Such buffer volumes were introduced by Stigebrandt (1983) and discussed by, for instance, Stigebrandt and Gustafsson (2003). The presence of a buffer volume delays the onset of flow events and reduces the importance of high-frequency fluctuations. An appropriate value of the buffer volume will be determined by tuning in Sect. 3.2.
An occasional shift in flow, which is too small for the buffer volume to be completely filled (emptied), will only pause the flow event. If the pause is too long, a new flow event starts when the buffer volume is restored. This buffer restoration time limit will be tuned so that inflow event lengths match the observed inflows; see Sect. 3.2. Finally, for each flow event, an average flow rate is calculated from the cumulated sum of water flow during the event.

\subsubsection{The freshwater pool in the entrance area}

To compute the salinity $S_{\text {in }}$ of the inflowing new deepwater, we need to know the mixture of freshwater and seawater. The latter is the deepwater in Kattegat, which is modified Skagerrak water. This is computed from the amount of freshwater in the entrance area, as shown in Sect. 2.1.3 below. Therefore, we construct a model of the freshwater pool in the entrance area. The thickness of the freshwater pool, $H_{\mathrm{fK}}$, is controlled by $Q_{\mathrm{BS}}$ and the salinity of this flow, the freshwater supply to the entrance area, $Q_{\mathrm{fK}}$, and freshwater outflow from the entrance area to Skagerrak, $Q_{\mathrm{fS}}$.

The rate of change of freshwater thickness, $\mathrm{d} H_{\mathrm{fK}} / \mathrm{d} t$ in the entrance area, can be calculated from the following continuity equation for freshwater:

$$
\begin{gathered}
A_{\mathrm{K}} \frac{d H_{\mathrm{fK}}}{\mathrm{d} t}=Q_{\mathrm{fK}}+Q_{\mathrm{outBS}} \frac{S_{0}-S_{\mathrm{B}}}{S_{0}} \\
-Q_{\mathrm{inBS}} \frac{S_{0}-S_{\mathrm{in}}}{S_{0}}-Q_{\mathrm{fS} .}
\end{gathered}
$$

Here $A_{\mathrm{K}}$ is the horizontal area of the freshwater pool, $S_{\mathrm{B}}$ the salinity of the water flowing out from the Baltic Sea and $S_{0}$ the salinity of the seawater in Kattegat. The exact value of $A_{\mathrm{K}}$ is determined by model tuning in Sect. 3.2.

The freshwater outflow from the entrance area to Skagerrak can be described as in Stigebrandt and Gustafsson (2003) by

$$
Q_{\mathrm{fS}}=\frac{g \beta S_{0} H_{\mathrm{fk}}^{2}}{2 f} .
$$

Here $g$ is the acceleration of gravity, $f$ the Coriolis parameter and $\beta \approx 8 \times 10^{-4}$ the salt contraction coefficient, defined by the following approximate equation of the state of seawater:

$\rho=\rho_{\mathrm{f}}(1+\beta S)$,

where $\rho_{\mathrm{f}}$ is the density of freshwater and $S$ is the salinity. This equation is applicable when density variations are essentially due to salinity variations, which is the case in the entrance area.

\subsubsection{Properties of new deepwater from the entrance area}

The new deepwater flowing into the Baltic Sea is a mixture of freshwater and deepwater from the entrance area. Its salinity 
$S_{\text {in }}$ can be calculated from the following empirical equation (Stigebrandt and Gustafsson, 2003):

$S_{\text {in }}=S_{0} \frac{H_{\mathrm{K}}-H_{\mathrm{fK}}}{H_{\mathrm{K}}}$.

The thickness $H_{\mathrm{K}}$ is an empirical constant, which is tuned in order to achieve conservation of salt in the Baltic Sea system; see Sect. 3.2. Equation (5) is valid as long as $S_{\text {in }}>S_{\mathrm{B}}$ because the inflowing new deepwater must be saltier than the surface water in the Arkona Basin.

Other state variables of the new deepwater, e.g., oxygen concentration and temperature, represented here by the dummy $c_{\text {in }}$, are calculated according to

$c_{\text {in }}=c_{\text {surf }} \frac{S_{0}-S_{\text {in }}}{S_{0}}+c_{0} \frac{S_{\text {in }}}{S_{0}}$.

Here, $c_{0}$ and $c_{\text {surf }}$ are approximated by monthly means of the seawater and surface values in the entrance area as described in Sect. 3.1.

In the model we use the event average of $Q_{\text {inBS }}$ and $Q_{\text {outBS }}$ for each time step during a flow event, as described in Sect. 2.1.1. However, the salinity, temperature and oxygen concentration of inflowing new deepwater, computed using Eqs. (5) and (6), change for each time step.

\subsubsection{The deepwater pool in the Arkona Basin}

Because new deepwater from the entrance area is denser than the surface water in the Arkona Basin, it descends along the bottom as a dense bottom current. By mixing with overlying water, the volume flow increases and the salinity (density) decreases. The entrainment of ambient water into the dense bottom current is computed using the plume model in Stigebrandt and Kalén (2013), but with a reversed, i.e., downward, travelling direction and with a value of the empirical entrainment coefficient, EA, that will be tuned, see Sect. 3.2, in order to achieve a good fit with observations. The properties of the entrained water are described by monthly averages of observations from $15 \mathrm{~m}$ depth in the Arkona Basin; see Sect. 3.1.

After entrainment, the dense bottom current has the flow rate $Q_{\text {inA }}$ and salinity $S_{\text {inA }}$ when it reaches the halocline in the Arkona Basin. Below this is a thoroughly mixed pool of dense deepwater that is replenished by the inflowing new deepwater. The pool loses water by the geostrophic flow of deepwater out from the Arkona Basin. The thickness of the Arkona pool, $H_{\mathrm{A}}$, changes according to the following equation:

$$
\frac{\mathrm{d}\left[A_{\mathrm{A}} \times H_{\mathrm{A}}\right]}{\mathrm{d} t}=Q_{\text {inA }}-Q_{\text {outA }} .
$$

Here $A_{\mathrm{A}}$ is the depth-dependent area of the pool and $Q_{\text {outA }}$ is the baroclinic geostrophic outflow from the pool, which can be computed as in Stigebrandt (1987a); thus,

$Q_{\text {outA }}=\frac{g^{\prime} H_{\mathrm{A}}^{2}}{2 f}$.
In this equation, $g^{\prime}=g \Delta \rho / \rho_{\mathrm{f}}$ where $\Delta \rho$ is the density difference between the pool water, salinity $S_{\mathrm{A}}$, and the water overlying it, salinity $S_{\mathrm{B}}$. Using Eq. (4) gives $\Delta \rho / \rho_{\mathrm{f}}=$ $\beta\left(S_{\mathrm{A}}-S_{\mathrm{B}}\right)$. The salinity $S_{\mathrm{A}}$ of the pool water changes according to the following equation:

$\frac{\mathrm{d}\left[S_{\mathrm{A}} \times A_{\mathrm{A}} \times H_{\mathrm{A}}\right]}{\mathrm{d} t}=Q_{\text {inA }} S_{\text {inA }}-Q_{\text {outA }} S_{\mathrm{A}}$.

Temperature and oxygen concentrations are computed analogously. $Q_{\text {outA }}$ may empty the pool within a few weeks. This allows us to assume that the residence time of the pool water in the Arkona Basin is so short that oxygen consumption in the pool may be neglected for simplicity. The validity of this assumption is discussed in Sect. 4.2 below.

\subsubsection{The Bornholm Basin model}

The water flowing out of the Arkona Basin is feeding a dense bottom current in the Bornholm Basin that, after entrainment of ambient water, is interleaved in the stratified basin. It then has the volume flow $Q_{\mathrm{inB}}$ and the salinity $S_{\mathrm{inB}}$. The computations of the flow in the dense bottom current are performed in the same way as described in Sect. 2.1.4 above. As described in Sect. 3.2 below, the empirical entrainment coefficient for the Bornholm Basin, EB, is tuned in order to achieve a good fit between model results and observations.

The outflow from the Bornholm Basin is geostrophic, driven by the horizontal west-east baroclinic pressure gradient between the Bornholm Basin and the Stolpe Channel. To resolve the flow vertically, we assume that the current speed, $v(z)$, is proportional to the horizontal baroclinic pressure gradient $\mathrm{dP}(z)$ at each depth $z$; thus,

$v(z) \sim \mathrm{dP}(z)$.

The difference in baroclinic pressure between the two basins, $\mathrm{dP}(z)$ equals $P_{\mathrm{BB}}(z)-P_{\mathrm{SC}}(z)$. It is calculated using daily time series, interpolated from observed profiles, from the Stolpe Channel (pressure $\left.P_{\mathrm{SC}}(z)\right)$ and modeled profiles from the Bornholm Basin (pressure $P_{\mathrm{BB}}(z)$ ).

We then normalize $v(z)$ so that the total outflow from the Bornholm Basin, i.e., the sum of the flows in all flowing layers, equals the flow we obtain from Eq. (8) modified for use in the Bornholm Basin. We use the salinity $S_{\mathrm{SC}}$ in the topmost $30 \mathrm{~m}$ in the Stolpe Channel to compute the reference salinity corresponding to $S_{\mathrm{B}}$ used in Sect. 2.1.4 above.

Our goal is to achieve a good model of hydrographic and oxygen conditions below $60 \mathrm{~m}$ in the Bornholm Basin. Since the new deepwater is not in contact with the sea surface after having entered the Arkona Basin, we choose not to model the upper layers driven by processes at the sea surface. Instead, we use interpolated observational data to describe the upper layers.

The rate of oxygen consumption in the basin, OXC, should vary with the export production from the euphotic zone, which should be proportional to the total phosphorus content, 
$\mathrm{TP}$, in the 0-40 m layer in winter. The reference oxygen consumption rate from Stigebrandt and Kalén (2013) (OXC $\mathrm{OSK}_{\mathrm{SK}}$ was accordingly multiplied by the factor $\mathrm{TP} / \mathrm{TP}_{n}$, where $\mathrm{TP}_{n}$ is the average phosphorus content in the period 1990-2010.

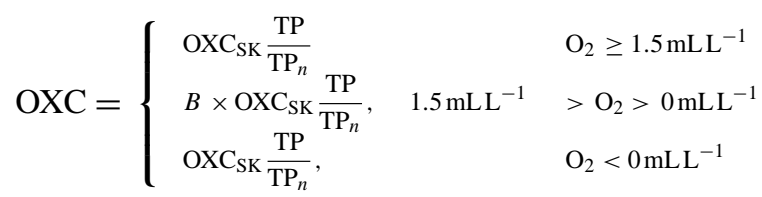

To adapt consumption to observations, we need to decrease the consumption rate by a factor $B$ in the interval $1.5>\mathrm{O}_{2}>0 \mathrm{mLL}^{-1}$; see Sect. 3.2. The reason for this is oxidation due to reduction of nitrate, nitrite and iron and manganese oxides/hydroxides. Equation (11) is used during stagnant conditions without advective water exchange. However, when the bottom water is oxidized by inflowing new deepwater, it is assumed that both hydrogen sulfide and ammonia, if present in the water column, are oxidized as described in Sect. 3.1. To oxidize 1 mole of hydrogen sulfide to sulfate, 2 moles of oxygen are needed, and to oxidize 1 mole of ammonium to nitrate, 1.5 moles of oxygen are needed.

\subsection{Biological issues}

\subsubsection{Critical oxygen concentrations and re-colonization}

In their reviews of marine benthic hypoxia, Diaz and Rosenberg (1995) and Karlson et al. (2002) concluded that critical oxygen concentrations for marine benthic animals varied between species. Mass mortality occurred when the oxygen concentration dropped below the range 0.5 to $1 \mathrm{~mL} \mathrm{~L}^{-1}$. Rosenberg et al. (2002) studied the reactions of benthic animals in the field during successively declining oxygen concentrations and found that mass mortality occurred at $0.7 \mathrm{~mL} \mathrm{~L}^{-1}$. However, behavioral responses and effects on reproduction occur in higher concentrations - commonly around $2 \mathrm{~mL} \mathrm{~L}^{-1}$.

The value of $2 \mathrm{mLL}^{-1}$ has been used as the limit below which hypoxia is defined and hypoxic waters are considered to harbor only a reduced benthic macrofauna under stress with adverse behavior and lack of reproduction ability (Conley et al., 2009a; Diaz and Rosenberg, 1995). In hypoxic areas where the sediments also contain toxic hydrogen sulfide close to the sediment surface, the conditions will be particularly unsuitable for benthic animals. Where oxygen minimum zones occur naturally, like in the eastern Pacific, animals are adapted to oxygen deficiency and tolerate oxygen levels close to zero (Levin, 2003). Such adaptations have not occurred in the Baltic, which is a young sea established after the last glaciation (Elmgren, 2001). Fish species are generally less tolerant to low oxygen concentrations and show avoidance reactions and reproductive failure in oxygen saturations less than $50 \%\left(\approx 4 \mathrm{~mL} \mathrm{~L}^{-1}\right)$ (Breitburg, 2002).
The recovery process of a formerly hypoxic/anoxic system that is re-oxygenated depends on the severity and extent to which the system was disturbed. The succession of benthic animals will most probably follow the Pearson and Rosenberg (1978) paradigm, which shows that the colonization begins with small, opportunistic species in high numbers, which will facilitate the sedimentary habitat for the later successional stages. Transitory immigrants will follow the pioneering stages and, finally, a more mature benthic community will establish itself. In areas where the sediments have a high organic content because of heavy loadings, the time of recovery to pre-pollution levels could be 6 to 8 years (Rosenberg, 1976). In a Swedish fjord, where the low oxygen concentrations caused mass mortality, but the near-bottom water was soon re-oxygenated, the recovery of the benthic fauna to pre-hypoxic compositions in this case took about 2 years (Rosenberg et al., 2002), the reason being that the sediment was not over-enriched by organic matter. In an experiment with oxygenation of the basin water in the usually anoxic By Fjord, on the western coast of Sweden, colonization of the bottoms started after about 1 year, when the sediment surface had been oxidized (Stigebrandt et al., 2014b).

\subsubsection{The cod reproduction volume (CRV)}

The cod reproduction volume (CRV) is defined as the water volume where the physical properties allow the survival of cod eggs, a prerequisite for successful cod spawning. The criteria that need to be fulfilled are salinity $S>11$, oxygen concentration $\mathrm{O}_{2}>2 \mathrm{mLL}^{-1}$, and temperature $T>1.5^{\circ} \mathrm{C}$. Vallin et al. (1999) conclude in their review that the combination of high salinity and high availability of oxygen is necessary for large recruitment of cod in the Baltic Sea. Thus, large recruitment is only possible after major inflows of new deepwater. Since inflow of new deepwater in general occurs during the winter months (Matthäus and Schinke, 1994), and oxygen consumption causes a reduction in the oxygen concentration over time, the CRV will be smaller later in the spawning season (Vallin et al., 1999). Under present environmental conditions, the Bornholm Basin has been shown to be the most favorable area for successful cod reproduction in the Baltic Sea (MacKenzie et al., 2000). The season for cod spawning has shifted from the spring months towards the summer months (e.g., Hinrichsen et al., 2007; Vallin et al., 1999). To reveal seasonal effects, CRV in the second and third quarters of the year should be presented separately.

\section{Data and tuning}

\subsection{Data}

To calculate the inflow $Q_{\mathrm{BS}}$, we use Eq. (1), which needs data on the horizontal mean sea level $h$ and the freshwater supply. For a first estimate of $Q_{\mathrm{BS}}$ with the temporal resolution of 1 day, we use 5 day running averages of the observed 
sea level in Stockholm. Strictly speaking, one should use the horizontal mean sea level of the Baltic Sea $h$ for the computations of $Q_{\mathrm{BS}}$, but since Stockholm is situated in the nodal line of the first mode of sea surface oscillations, we use the sea level in Stockholm as a proxy for horizontal mean sea level (e.g., Samuelsson and Stigebrandt, 1996). For $Q_{\mathrm{fBS}}$, we use a time series of monthly values of river runoff to the Baltic Sea, with the Arkona Basin as the western limit. To this, we add the average annual cycle for precipitation minus evaporation from the sea surface (Rutgersson et al., 2002). The average of $Q_{\mathrm{fBS}}$ in the period 1990-2010 was calculated to be $15500 \mathrm{~m}^{3} \mathrm{~s}^{-1}$.

The start value for $H_{\mathrm{fK}}$, the thickness of the freshwater pool in the entrance area, is estimated from salinity observations from Anholt E $\left(56^{\circ} 40^{\prime} \mathrm{N}, 12^{\circ} 7^{\prime} \mathrm{E}\right.$, in Fig. 1) from the end of November 1989 to the end of January 1990. Of 1636 available vertical hydrographic profiles from the southern Kattegat $\left(55^{\circ} 0^{\prime}-56^{\circ} 12^{\prime} \mathrm{N}, 10^{\circ} 48^{\prime}-12^{\circ} 0^{\prime} \mathrm{E}\right.$, white box in Fig. 1), all temperature and oxygen data from $5 \mathrm{~m}$ depth (1635 and 782, respectively) are used to compute monthly averages to represent the annual cycle of the surface layer in the entrance area. All temperature and oxygen data measured in deepwater of salinity $\geq 32$ are used similarly to compute monthly averages representing the seawater annual cycle. The properties of the inflowing new deepwater are then given by the monthly averages and the proportions of surface and deepwater in the specific inflow, as described by Eq. (6).

We use all available data (historic vertical hydrographic profiles) at $15 \mathrm{~m}$ depth from 1990 to 2010 from the eastern half of the Arkona Basin $\left(54^{\circ} 42.0^{\prime}-55^{\circ} 9.0^{\prime} \mathrm{N}, 13^{\circ} 41.4^{\prime}-\right.$ $14^{\circ} 18.0^{\prime} \mathrm{E}$, dashed box in Fig. 1) (455 observations) to compute monthly averages of salinity, temperature and oxygen describing the properties of the upper layer in the Arkona Basin. Water with these properties is entrained into the dense bottom current with new deepwater. 421 observed vertical salinity profiles from the same area, going down to at least $35 \mathrm{~m}$ depth and with bottom salinity greater than 11.6 , were used to calculate the baroclinic outflow from the dense bottom pool according to Stigebrandt (1987a). The observed outflow is compared to model estimates for different values of the entrainment coefficient EA; see Sect. 3.2 below.

In the Bornholm Basin, we use 361 profiles from station BY4 $\left(55^{\circ} 23.0^{\prime} \mathrm{N}, 15^{\circ} 20.0^{\prime} \mathrm{E}\right.$, white o in Fig. 1) and 247 observed vertical hydrographic profiles from station BY5 $\left(55^{\circ} 15.0^{\prime} \mathrm{N}, 15^{\circ} 59.0^{\prime} \mathrm{E}\right.$, white $\mathrm{x}$ in Fig. 1) from 1990 to 2010 for the following computations. An average of BY5 profiles from 17 November 1989 and 24 January 1990 is used for the initial water column properties of the model on the start date (3 January 1990). The vertical resolution varies throughout the profiles (decreases with depth) and also somewhat between profiles, due to missing data values. The most common resolution is $5 \mathrm{~m}$ between 0 and $20 \mathrm{~m}$ depth, and then a $10 \mathrm{~m}$ resolution down to $90 \mathrm{~m}$. Data gaps are more common in the winter, when storms and ice cover stop the observation vessels from reaching the stations. The observed salinity, tem- perature and oxygen concentration profiles from BY4 and BY5 are interpolated to form daily time series that are then compared to the corresponding time series resulting from the model. These vertical profiles are also used to compute the "observed" cod reproduction volume during the second and third quarters of each year from 1990 to 2010 . This is then compared to the modeled cod reproduction volume. The interpolated daily time series from BY4 are chosen to represent the state variables (salinity, temperature and oxygen) above $30 \mathrm{~m}$ depth in the Bornholm Basin.

From observations obtained at BY5, we construct time series of the annual winter content of total phosphorus in the uppermost $40 \mathrm{~m}$, TP, to estimate the year-to-year variation of the export production supplying organic matter below $60 \mathrm{~m}$ depth in the Bornholm Basin as described in connection with Eq. (11).

From observations from depths greater than or equal to $85 \mathrm{~m}$ at BY5 (43 observations), we have estimated that changes in the mole ratio between ammonium and hydrogen sulfide equals $1 / 5$ under anoxic conditions. Furthermore, we estimated that the concentration of ammonium when the water turns from oxic to anoxic equals $4 \mathrm{mmol} \mathrm{m}^{-3}$. Ammonium and hydrogen sulfide are oxidized when water exchange mixes old oxygen-free deepwater and new deepwater as described in Sect. 2.1.5.

219 vertical salinity and temperature profiles from the Stolpe Channel area $\left(55^{\circ} 9^{\prime}-55^{\circ} 24^{\prime} \mathrm{N}, 16^{\circ} 42^{\prime}-17^{\circ} 54^{\prime} \mathrm{E}\right.$, black box in Fig. 1) are used to form the interpolated daily time series used to calculate $P_{\mathrm{SC}}$ for the calculation of the geostrophic outflow from the Bornholm Basin into the Baltic Sea. The same data set is used to calculate a time series of $S_{\mathrm{SC}}$, the mean salinity of the upper $30 \mathrm{~m}$ in Stolpe Channel.

Finally, hypsographic data for the studied sub-basins of the Baltic Sea were obtained from Seifert et al. (2001). The horizontal surface area of the Baltic Sea, $A_{\mathrm{BS}}$, used in Eq. (1), equals $3.7 \times 10^{11} \mathrm{~m}^{2}$. For other data sources, see the Acknowledgements.

\subsection{Tuning}

Model coefficients have been tuned in order to improve the match between computed and observed data. Accordingly, the buffer volume located at the entrance sills equals $30 \mathrm{~km}^{3}$, with a restoration time limit of 7 days. When the model run begins, the buffer volume is empty. This approach gives long-term average flow rates to/from the Baltic of $16400 / 32100 \mathrm{~m}^{3} \mathrm{~s}^{-1}$, respectively, for the investigated period 1990-2010. Observations from $15 \mathrm{~m}$ depth in the Arkona Basin for the same period give an average outgoing salinity of 7.9. If salt content and volume of the Baltic are assumed to be preserved over the period 1990-2010, new deepwater needs to have an average salinity of 15.5. This is achieved in the model by setting $S_{0}$ equal to 33 and $H_{\mathrm{K}}$ in Eq. (5) equal to $6.7 \mathrm{~m}$. The freshwater pool area, $A_{\mathrm{K}}$, was adjusted to avoid overly salty inflows. The value 


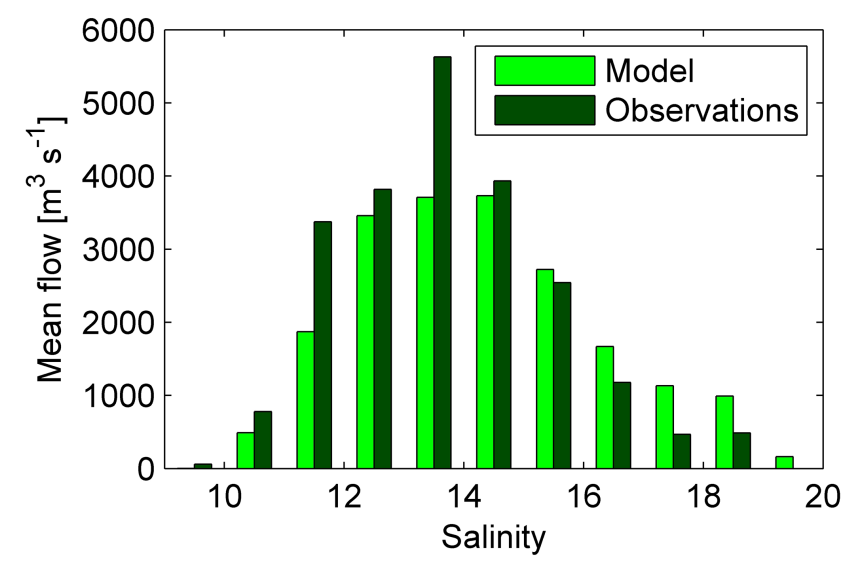

Figure 3. Distribution of observed and modeled average flow rates among different salinities for the baroclinic outflow from the Arkona Basin.

$42000 \mathrm{~km}^{2}$, proposed by Stigebrandt (2001), gives good correspondence between the model and observations. The thickness $H_{\mathrm{A}}$ of the dense Arkona pool is measured upwards from $41 \mathrm{~m}$ depth, which is the sill depth of the Arkona Basin (Stigebrandt, 1987a).

The empirical entrainment coefficient of dense bottom currents, which determines the rate of increase in the volume transport per unit depth, was tuned to give a good fit between model results and observations. For the Arkona Basin, $\mathrm{EA}=0.02 \mathrm{~m}^{-1}$ gives a satisfactory relationship between salinity and volume flowing out from the Arkona Basin, as seen in Fig. 3. For the Bornholm Basin, $\mathrm{EB}=0.01 \mathrm{~m}^{-1}$ gave a good fit between observations and modeled values of salinity, oxygen and temperature. A wide and thin bottom gravity current, flowing on a sloping plane, entrains more ambient water than a thicker and narrower current that runs in a canyon (Stigebrandt, 1987b). This qualitatively explains the difference between EA (plane) and EB (canyon).

The salinities $S_{\text {in }}$ of seven large modeled inflows into the Bornholm Basin were adjusted manually in order to get a better fit between modeled and observed salinity in the Bornholm Basin. The salinity was slightly increased in the inflows that occurred in 1994, 2003 and 2010 and slightly decreased for the inflows in 1997 and 2007. The salinity in two subsequent inflows during 1998 was increased and decreased, respectively.

To conform to observations in the Bornholm Basin, we halved the oxygen consumption rate for the interval $1.5>\mathrm{O}_{2}>0 \mathrm{mLL}^{-1}$, thus using $B=0.5$ in Eq. (11). Although interesting in itself, we found no strong reason for the present investigation to fine-tune the parameterization of oxygen consumption by, for instance, letting $B$ vary in the interval $0-1.5 \mathrm{mLL}^{-1}$ or using a $B$ value different from 1 in the anoxic case.

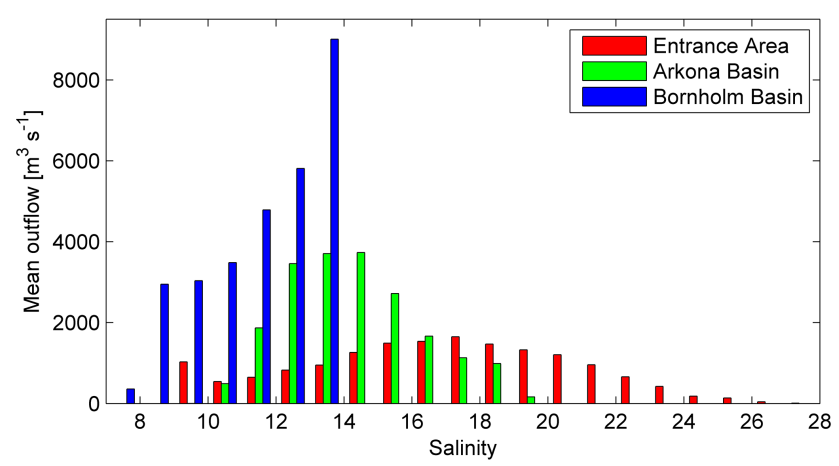

Figure 4. Distribution of the average volume flow among different salinities for the modeled deepwater flows from the entrance area, the Arkona Basin and the Bornholm Basin.

\section{Results and discussion}

The modeled flows of new deepwater in different salinity intervals from the Baltic entrance area, out from the Arkona Basin and out from the Bornholm Basin, respectively, are shown in Fig. 4. As expected, the salinity decreases and the volume flow increases downstream due to mixing in the basins.

\subsection{Arkona Basin - deepwater flow estimates using historic vertical hydrographic profiles versus the pool model}

The distributions of average flow rates among different salinities according to the Arkona Basin pool model and computed from hydrographical observations are shown in Fig. 3. We find that hydrographical observations for the period 1990-2010 give an ensemble average flow rate from the dense pool of $22300 \mathrm{~m}^{3} \mathrm{~s}^{-1}$ with an average salinity of 13.7 , which is similar to the results estimated from hydrographical observations for an earlier period in Stigebrandt (1987a). The corresponding values according to our pool model are $19900 \mathrm{~m}^{3} \mathrm{~s}^{-1}$ and 14.4 , respectively. The modeled outflow of deepwater from the Arkona Basin thus follows the observations rather well.

It was shown in Stigebrandt (1987a) that, due to the large variability of the flow of new deepwater in the Arkona Basin, about 500 independent observations are needed to estimate the mean inflow with an error of less than $10 \%$. Thus, from the number of observations available (451, see Sect. 3.1), we expect an error within the range $\pm 10 \%$. This means that the computed flow might be closer to reality than statistics produced by the observations. The evolution of observed and modeled vertical distributions of salinity, temperature and oxygen shown below may deviate rather much due to the combination of large variability and sparse observations. Another reason for deviations is the fact that model results are from a horizontally integrated model with high temporal res- 
olution, while observations are obtained at a few depths of a sparsely visited location (BY4).

\subsection{Bornholm Basin - observed and modeled vertical hydrographic profiles}

The observed salinity at station BY4 (Fig. 5a) can be compared to the modeled salinity (Fig. 5b). The modeled salinity is well correlated with observations below $40 \mathrm{~m}$. The evolution of the salinity is clearly governed by three different physical processes that are included in the model: (i) during deepwater inflows, salinity increases and the halocline rises; (ii) between inflows, vertical diffusion dominates, whereby salinity decreases with time; and (iii) outflows through the Stolpe Channel lower the halocline. The observed and modeled temperatures are shown in Fig. 6.

The observed oxygen concentration at BY4 (Fig. 7a) is compared to modeled levels in Fig. 7b. In the plots, hydrogen sulfide is expressed as negative oxygen such that 2 moles of negative oxygen correspond to 1 mole of hydrogen sulfide. The actions of the three advection-diffusion processes seen in Fig. 5 can also be seen in Fig. 7. However, in addition, oxygen is influenced by oxygen consumption (also included in the model) that decreases the oxygen concentration. Vertical diffusion of oxygen from above tends to compensate for oxygen consumption in the enclosed basin. The modeled oxygen concentration largely follows the observations from station BY4, but also fits data from station BY5. In Fig. 7a we do not see any traces of small volumes of water with relatively low oxygen concentrations that might come from the Arkona Basin in the fall. This is discussed further below.

The comparison between observations and the reference model run (Figs. 5a and b, 7a and b) shows that the timing of the modeled inflows corresponds well to the observations in the Bornholm Basin. However, the observed vertical hydrographic profiles used for validating the model generally have a monthly time resolution, usually with still lower resolution during winter months. The resolution of observations is thus very low compared to the daily resolution of the model results. It is therefore possible that the observations may miss the precise timing of the inflow and the exact water properties just after a deepwater inflow. Sometimes the observed bottom salinities appear to be higher than the modeled bottom salinities. This suggests that the model produces a more homogenous water column in the deepest parts of the basin, but with a similar salt content to that observed in the whole water column.

Observations show that the halocline uplift after larger inflows, such as the one in early 2003, can persist for up to 1 year. In the model, such uplifts seem to decay more quickly, suggesting that the modeled outflow might be too fast. However, another explanation may be that the vertical resolution of observations is typically $10 \mathrm{~m}$, while the model resolution equals $1 \mathrm{~m}$. Observations would then give the im-

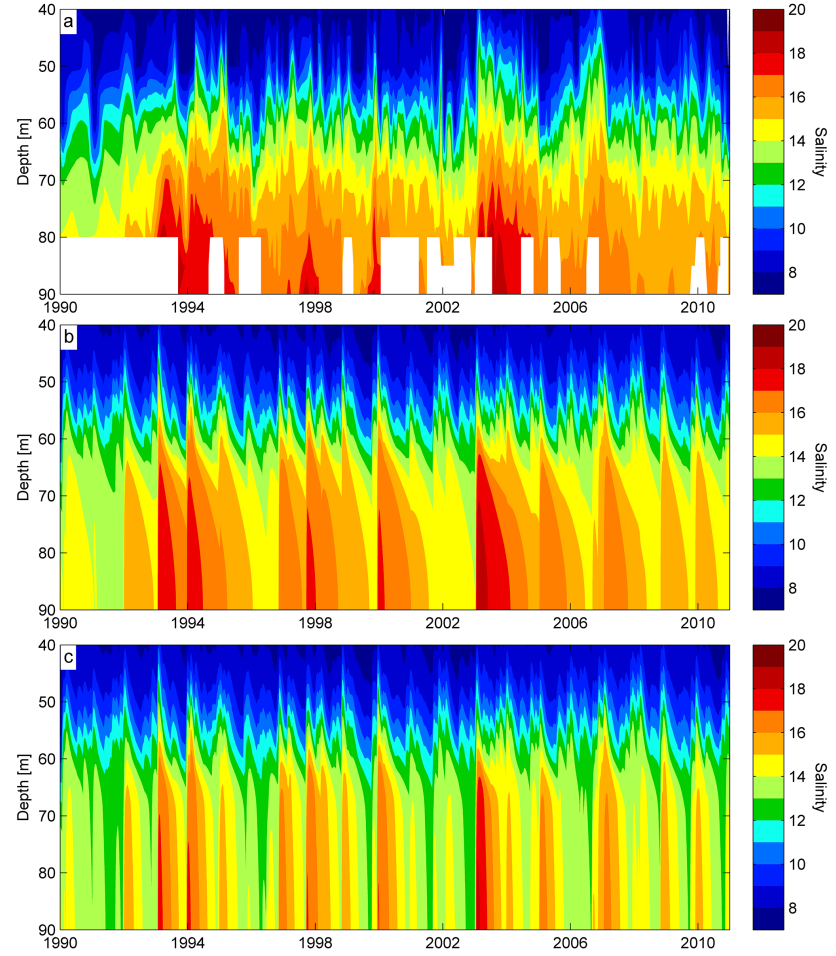

Figure 5. (a) The observed salinity from BY4, (b) the modeled salinity (reference run) and (c) the modeled salinity when pumping $1000 \mathrm{~m}^{3} \mathrm{~s}^{-1}$ from $30 \mathrm{~m}$ depth down to $90 \mathrm{~m}$.

pression of a persistent halocline in the depth interval 50 to $60 \mathrm{~m}$. Since the modeled conditions in the basin water below sill depth $(60 \mathrm{~m})$ appear to follow observations quite well, the possibly slightly too rapid outflow (above $60 \mathrm{~m}$ depth) should not be critical for the results in the basin water (below $60 \mathrm{~m}$ depth).

It is obvious that the modeled temperature (Fig. 6b) in the halocline (50-65 m depth) is often too low in summer and too high in winter compared to the observed temperature (Fig. 6a). One reason for the deviation in winter may be that our model lacks surface dynamics and deep vertical convection occasionally reaching down to the sill level. Deviations all around the year may be due to overly sparse data in the entrance area, where water temperatures are given by monthly means, meaning that inflows with extreme temperatures are missed. However, since density variations in the Bornholm Basin are dominated by salinity variations, it is of little dynamical importance that the modeled temperature is smoothed.

Our model assumes that there is no oxygen consumption in the new deepwater when passing the Arkona Basin. We will investigate whether or not this assumption may be violated in periods. The volume of the basin water, below the sill level at $41 \mathrm{~m}$ depth, in the Arkona Basin is about $12 \mathrm{~km}^{3}$, estimated using the topographic database in Seifert et al. (2001), which is only $8 \%$ of the volume of the basin 


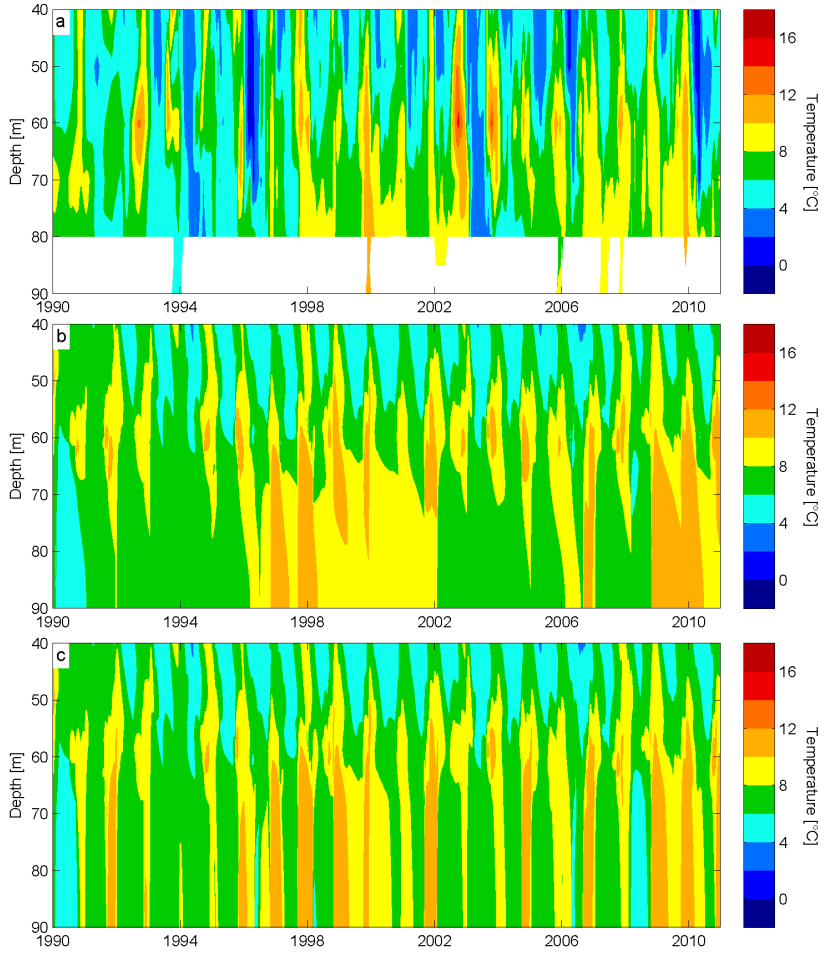

Figure 6. (a) The measured temperature from BY4, (b) the modeled temperature (reference run) and (c) the modeled temperature when pumping $1000 \mathrm{~m}^{3} \mathrm{~s}^{-1}$ from $30 \mathrm{~m}$ depth down to $90 \mathrm{~m}$.

water in the Bornholm Basin. If initially of high salinity, water may stay in the basin from spring to fall, whereby it may obtain a low oxygen concentration due to local consumption. The lowest record of oxygen concentration in the Arkona Basin, according to the data available for this study, equals $0.33 \mathrm{mLL}^{-1}\left(0.47 \mathrm{mg} \mathrm{L}^{-1}\right)$ (December 1997) $\left(1 \mathrm{mLL}^{-1} \approx 1.4 \mathrm{mg} \mathrm{L}^{-1}\right)$.

In Table 1 are given volume and mean salinity and mean oxygen concentration of all 10 cases of hypoxic water with volumes greater than $3 \mathrm{~km}^{3}$ estimated from hydrographical observations in the Arkona Basin during the period 19902011 (22 years). When the basin water resting in the Arkona Basin is eventually flushed by a new denser deepwater, parts of the flushed basin water will be entrained into the new deepwater, while the remainder is lifted above the sill level; cf. the process of water exchange in the By Fjord (Stigebrandt et al., 2014b). After the uplift, the flushed deepwater will be contained in a rather thin layer for topographical reasons. For example, a layer of volume $10 \mathrm{~km}^{3}$ centered at $35 \mathrm{~m}$ depth will be only $2 \mathrm{~m}$ thick. This layer has a lower oxygen concentration than the surrounding water, which is why oxygen will diffuse efficiently into the layer from both above and below. Hereby, the oxygen content is expected to increase already before the water in this layer exits through the Bornholm Channel.
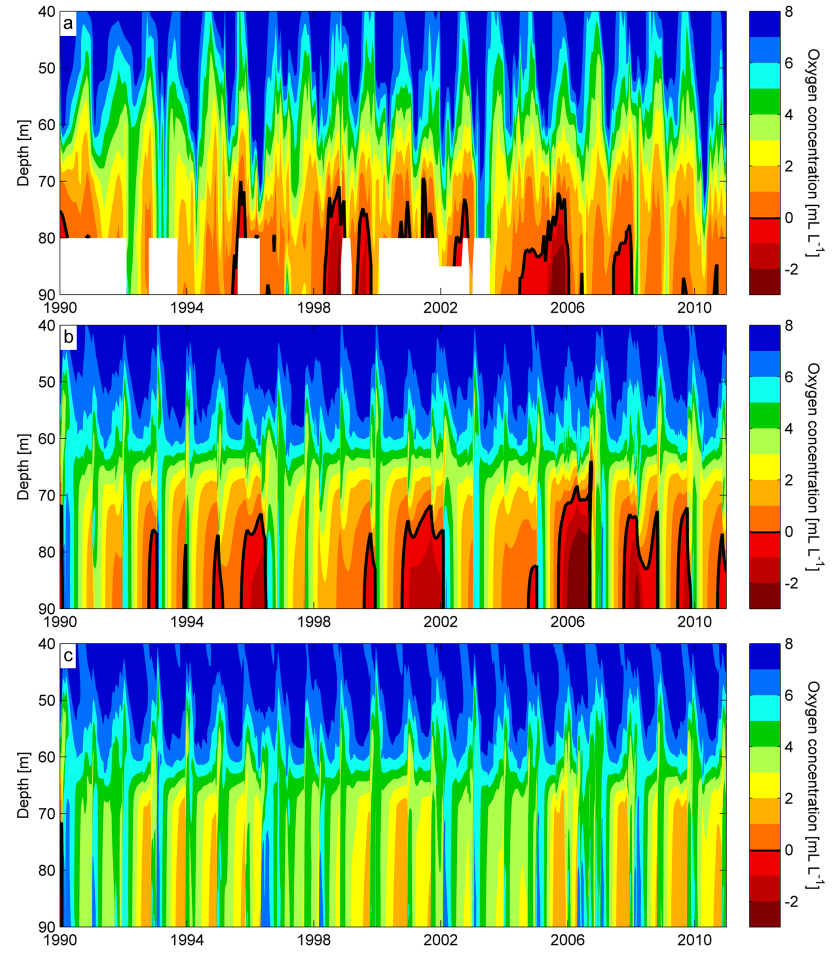

Figure 7. (a) The measured oxygen content from BY4, (b) the modeled oxygen content (reference run) and (c) the modeled oxygen content when pumping $1000 \mathrm{~m}^{3} \mathrm{~s}^{-1}$ from $30 \mathrm{~m}$ depth down to $90 \mathrm{~m}$.

In the Bornholm Basin, the flushed basin water from the Arkona Basin will entrain ambient water of low salinity (average 9) and high oxygen content (average $6.7 \mathrm{mLL}^{-1}$ $\left(9.8 \mathrm{mg} \mathrm{L}^{-1}\right)$ ) at the rate $\mathrm{EB}$, meaning that the volume has increased by $30 \%$ when reaching $60 \mathrm{~m}$ depth. The estimated salinity and oxygen concentration of the water when reaching the depth of $60 \mathrm{~m}$ in the Bornholm Basin are given in Table 1. As can be seen, the water is in none of the cases hypoxic when reaching $60 \mathrm{~m}$, and the salinity is usually too low to permit penetration down into the deep basin. The figures for oxygen concentration given in Table 1 should be conservative, because the probably substantial diffusive supply of oxygen by vertical mixing in the Arkona Basin after the uplift discussed above is not accounted for.

\subsection{Hydrographical changes of pumping in the Bornholm Basin}

The model was run with the pumping turned on with an initial (jet) mixing rate $\alpha=10$, meaning an eleven-fold increase in the volume flow, and plume entrainment $E=0.05$, meaning a $5 \%$ increase in the volume flow when the buoyant plume rises by $1 \mathrm{~m}$. This fits well with the observed mixing of the pumped flow in the By Fjord experiment (Stigebrandt et al., 2014b). The natural vertical mixing in the basin is modeled as specified in Stigebrandt and Kalén (2013). The 
Table 1. Volume, $V(\mathrm{~A})$, mean salinity, $S(\mathrm{~A})$, and mean oxygen concentration, $\mathrm{O}_{2}(\mathrm{~A})$, of hypoxic water observed in the Arkona Basin during the period 1990-2011. Also shown are estimated salinity, $S(\mathrm{~B})$, and oxygen concentration, $\mathrm{O}_{2}(\mathrm{~B})$, when the water reaches $60 \mathrm{~m}$ depth in the Bornholm Basin.

\begin{tabular}{llllllll}
\hline Day & Month & Year & $V(\mathrm{~A})^{\mathrm{a})}$ & $S(\mathrm{~A})$ & $\mathrm{O}_{2}(\mathrm{~A})^{\mathrm{b})}$ & $S(\mathrm{~B})$ & $\mathrm{O}_{2}(\mathrm{~B})^{\mathrm{b})}$ \\
\hline 31 & 08 & 1992 & 23.35 & 14.33 & $0.90(1.29)$ & 13.1 & $2.28(3.25)$ \\
1 & 09 & 1994 & 15.13 & 15.07 & $1.57(2.24)$ & 13.82 & $2.80(3.99)$ \\
15 & 12 & 1997 & 15.13 & 16.62 & $1.09(1.55)$ & 14.86 & $2.42(3.46)$ \\
23 & 09 & 1998 & 19.09 & 14.12 & $1.50(2.14)$ & 12.94 & $2.74(3.91)$ \\
25 & 09 & 2002 & 15.13 & 16.66 & $1.69(2.41)$ & 14.89 & $2.89(4.12)$ \\
30 & 10 & 2007 & 19.09 & 14.53 & $1.20(1.71)$ & 13.25 & $2.50(3.57)$ \\
17 & 09 & 2008 & 19.09 & 14.42 & $1.46(2.09)$ & 13.17 & $2.70(3.86)$ \\
16 & 09 & 2009 & 11.50 & 15.30 & $1.82(2.61)$ & 13.85 & $2.99(4.27)$ \\
15 & 09 & 2010 & 15.13 & 13.64 & $1.53(2.18)$ & 12.57 & $2.77(3.95)$ \\
14 & 09 & 2011 & 8.26 & 13.01 & $1.33(1.90)$ & 12.08 & $2.61(3.72)$ \\
\hline
\end{tabular}

${ }^{\mathrm{a}}$ Volume is given in $\mathrm{km}^{3} .{ }^{\mathrm{b}}$ Oxygen values are given in $\mathrm{mLL}^{-1}\left(\mathrm{mg} \mathrm{L}^{-1}\right)$.

results with pumping turned on are compared to the model results with pumping turned off presented in Sect. 4.2 above. We are primarily interested in finding out the volume transport by pumping required to maintain oxic conditions in the deepwater. The water intake depth was set to $30 \mathrm{~m}$, but intake depths at 0 and $40 \mathrm{~m}$ were also tested for comparison. In all model runs, the horizontal pump outlet is at $90 \mathrm{~m}$ depth. The investigated pumping rates were 800,1000, 1200, 1500 and $4000 \mathrm{~m}^{3} \mathrm{~s}^{-1}$. At the present stage, it is not necessary to specify the number of pumps, their geographical location and the outlet velocity needed in practice to achieve the properties of the modeled pumping.

The salinity and oxygen content in the water column with a pumped volume flow of $1000 \mathrm{~m}^{3} \mathrm{~s}^{-1}$ can be seen in Figs. $5 \mathrm{c}$ and $7 \mathrm{c}$, respectively. Notice that pumping leads to an increased number of inflow events in the basin water and that the salinity never falls below 11 beneath $65 \mathrm{~m}$ depth. Notice also that the oxygen content for this pumping rate only rarely drops below $1.5 \mathrm{~mL} \mathrm{~L}^{-1}$ and never below $1 \mathrm{mLL}^{-1}$. It is also to be noted that, on all occasions when the oxygen content in the pumping scenario (Fig. 7c) drops below $2 \mathrm{mLL}^{-1}$, the oxygen content in the model reference run (Fig. 7b) is slightly too low compared to observations (Fig. 7a). The bottoms deeper than $75 \mathrm{~m}$, with an area of about $5000 \mathrm{~km}^{2}$, will be habitable for benthic biomass, as further discussed in Sect. 4.6. The oxygen conditions produced by the model in the basin water are discussed further below.

The effects of different pumping rates on the mean flow rate, the number and properties of inflow events and on the basin salinity, temperature and oxygen levels, represented by values from $75 \mathrm{~m}$ depth, are shown together with the effects on the CRV in Table 2. It can be seen that an increased pumping rate leads to an increased rate of water exchange at the greatest depths. For the highest pumping rates, we get the highest average inflow rates, but notice fewer inflow events, since inflow events merge; compare Table 2 for pumping rates 1500 and $4000 \mathrm{~m}^{3} \mathrm{~s}^{-1}$. Like in the
By Fjord experiment (Stigebrandt et al., 2014b), the average salinity in the basin is decreased by pumping. This explains why pumping allows for increased basin ventilation by inflows that previously were not able to penetrate to the bottom of the basin. The minimum basin salinity decreases approximately linearly with increased pumping rate (approximately -0.1 per $100 \mathrm{~m}^{3} \mathrm{~s}^{-1}$ ); thus, if the pumping rate exceeds $2200 \mathrm{~m}^{3} \mathrm{~s}^{-1}$, the minimum salinity may occasionally drop below 11, which affects, e.g., the minimum CRV for the highest investigated pumping rate $4000 \mathrm{~m}^{3} \mathrm{~s}^{-1}$ (see Table 2).

Inflows contribute 3 to 5 times more oxygen than the pumped water, dependent on the magnitude of the pumped volume flow (Table 2). By pumping $1000 \mathrm{~m}^{3} \mathrm{~s}^{-1}$, the inflow of oxygen by new deepwater is increased by $144 \%$. An additional increase in the oxygen inflow by about $56 \%$ is contributed by the pumped water. Both average and minimum oxygen levels in the basin water increase significantly with increased pumping. A pumped volume flow of $1000 \mathrm{~m}^{3} \mathrm{~s}^{-1}$ increases the average oxygen level at $75 \mathrm{~m}$ from 1.9 to $3.6 \mathrm{~mL} \mathrm{~L}^{-1}$. The minimum (average of the $2 \%$ lowest values) level increases from -2.4 (anoxic) to $1.4 \mathrm{~mL} \mathrm{~L}^{-1}$, respectively. The pumping makes particularly large difference in the deepest parts of the basin because the vertical downward motion in the whole basin, induced by the pumping, transports oxygen and other substances from higher levels much more efficiently than the natural vertical diffusion does; cf. Fig. 7c and an example in Stigebrandt and Kalén (2013).

In the fall, hypoxic basin water from the Arkona Basin may be exchanged and flow into the Bornholm Basin, as discussed at the end of Sect. 4.2. The oxygen deficit of a package of $20 \mathrm{~km}^{3}$ of water with an $\mathrm{O}_{2}$ concentration of $2.7 \mathrm{~mL} \mathrm{~L}^{-1}\left(3.9 \mathrm{mg} \mathrm{L}^{-1}\right)$ instead of $6.7 \mathrm{mLL}^{-1}$ $\left(9.8 \mathrm{mg} \mathrm{L}^{-1}\right.$ ) (oxygen deficit $6 \mathrm{mg}$ per $\mathrm{kg}$ water) equals $120 \mathrm{kton}$ of oxygen. The total oxygen supply in the reference

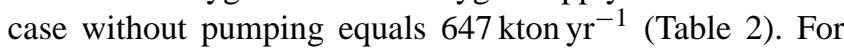
pumping $1000 \mathrm{~m}^{3} \mathrm{~s}^{-1}$, the supply is estimated at $1940 \mathrm{kton}$ 
Table 2. Model results for 1990-2010 with the pump intake placed at $30 \mathrm{~m}$ depth and for different pumping rates.

\begin{tabular}{|c|c|c|c|c|c|c|}
\hline $\begin{array}{l}\text { Pumped volume } \\
\text { flow }\left(\mathrm{m}^{3} \mathrm{~s}^{-1}\right)\end{array}$ & Ref. $^{a}$ & 800 & 1000 & 1200 & 1500 & 4000 \\
\hline 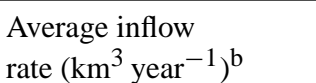 & 66.8 & 141.0 & 160.0 & 177.7 & 205.2 & 587.5 \\
\hline $\begin{array}{l}\text { Number of } \\
\text { inflows }{ }^{c}\end{array}$ & 17 & 38 & 45 & 50 & 47 & 37 \\
\hline $\begin{array}{l}\text { Average inflow } \\
\text { salinity }\end{array}$ & 15.89 & 15.05 & 14.90 & 14.79 & 14.69 & 14.08 \\
\hline $\begin{array}{l}\text { Average inflow of } \\
\mathrm{O}_{2}\left(\text { kton year }^{-1}\right)^{\mathrm{b}}\end{array}$ & 647 & 1385 & 1579 & 1769 & 2051 & 6076 \\
\hline $\begin{array}{l}\text { Flow of } \mathrm{O}_{2} \\
\text { via pump (kton year }{ }^{-1} \text { ) }\end{array}$ & 0 & 288 & 360 & 431 & 536 & 1438 \\
\hline $\begin{array}{l}\text { Average basin } \\
\mathrm{O}_{2}\left(\mathrm{mLL}^{-1}\right)^{\mathrm{e}}\end{array}$ & 1.92 & 3.44 & 3.64 & 3.81 & 4.04 & 5.10 \\
\hline $\begin{array}{l}\text { Minimum basin } \\
\mathrm{O}_{2}\left(\mathrm{mLL}^{-1}\right)^{\mathrm{f}}\end{array}$ & -2.41 & 1.26 & 1.38 & 1.45 & 1.68 & 3.78 \\
\hline $\begin{array}{l}\text { Average basin } \\
\text { salinity }\end{array}$ & 15.41 & 14.52 & 14.38 & 14.25 & 14.07 & 13.11 \\
\hline $\begin{array}{l}\text { Minimum basin } \\
\text { salinity }\end{array}$ & 13.34 & 12.57 & 12.46 & 12.32 & 12.09 & 10.80 \\
\hline $\begin{array}{l}\text { Average basin } \\
\text { temp }\left({ }^{\circ} \mathrm{C}\right)^{\mathrm{e}}\end{array}$ & 8.16 & 8.12 & 8.11 & 8.11 & 8.09 & 7.92 \\
\hline $\begin{array}{l}\text { Q1 of } \\
\text { CRV }\left(\mathrm{km}^{3}\right)^{\mathrm{g}}\end{array}$ & 41.9 & 57.2 & 65.7 & 81.1 & 100.6 & 112.2 \\
\hline $\begin{array}{l}\text { Minimum } \\
\text { CRV }\left(\mathrm{km}^{3}\right)^{\mathrm{h}}\end{array}$ & 15.2 & 54.0 & 54.0 & 54.0 & 54.0 & 0 \\
\hline
\end{tabular}

${ }^{a}$ Model reference values (pumping rate set to 0 ). ${ }^{b}$ Volumes reaching $90 \mathrm{~m} \mathrm{depth} .{ }^{\mathrm{c}}$ The number of inflows is defined as the number of new inflow events reaching $90 \mathrm{~m}$ and lasting at least $24 \mathrm{~h}$ after a minimum of 1 week of stagnation. ${ }^{\mathrm{d}}$ Volume-weighted average for salinities of the inflow of new deepwater. ${ }^{\mathrm{e}}$ The average of values from $75 \mathrm{~m}$ depth. ${ }^{\mathrm{f}}$ The average of the $2 \%$ lowest values at $75 \mathrm{~m}$ depth. ${ }^{\mathrm{g}}$ The average of the $25 \%$ smallest CRVs calculated for the cod spawning period, April to June and June to September. ${ }^{\mathrm{h}}$ Calculated for the cod spawning period, April to June and June to September.

(360 kton from pumping and 1580 kton from inflows). The oxygen supply has thus increased by $200 \%$. If we include the package with low oxygen content, the total supply decreases to $1820 \mathrm{kton}$. This gives an increase in the oxygen supply by $181 \%$. This should be a conservative estimate, because most of the packages in Table 1 should not reach the greatest depth of the Bornholm Basin at the suggested rate of pumping, as their salinity is too low. In addition, the packages from the Arkona Basin are released in September or later, which is too late in the year to affect the CRV, because the spawning occurs in the time period April-September. It would be relatively easy to complement the oxygenation system in the Bornholm Basin by a system in the Arkona Basin to keep the small deepwater volume there oxygenated and in this way to eliminate the possibility of low oxygen concentrations developing in the Arkona Basin. This would also be quite beneficial for the bottom fauna in the deepest part of the Arkona Basin.

The average basin temperature is $8.1^{\circ} \mathrm{C}$ in the reference case and does not change significantly with any of the tested pumping rates. Hence, the long-term basin average temperature does not appear to be affected by pumping when the pump intake depth is in the interval $30-40 \mathrm{~m}$. However, the average and maximum temperatures at $75 \mathrm{~m}$ depth increase by approximately $0.2^{\circ} \mathrm{C}$ if the water intake is located at the sea surface. The salinity changes very little if the intake depth is changed to 0 or $40 \mathrm{~m}$.

The changes in salinity due to pumping can easily be seen in Fig. 6 in Stigebrandt and Kalén (2013), which shows that the pumped winter water, of salinity about 8 , is interleaved in the lower part of the halocline, well below $60 \mathrm{~m}$ depth, due to strong mixing with the ambient deepwater. When interleaved, the volume flow of the pumped plumes has increased by a factor of 20 to 30 . Equally strong mixing of the pumped flow was observed in the By Fjord experiment, where the volume flow of pumped plumes increased by a factor of 30 before they were interleaved (Stigebrandt et al., 2014b). Because the pumped water is interleaved in the lower part of the halocline, the dynamics of the surface layer, including the local supply of nutrients and the production of organic mat- 


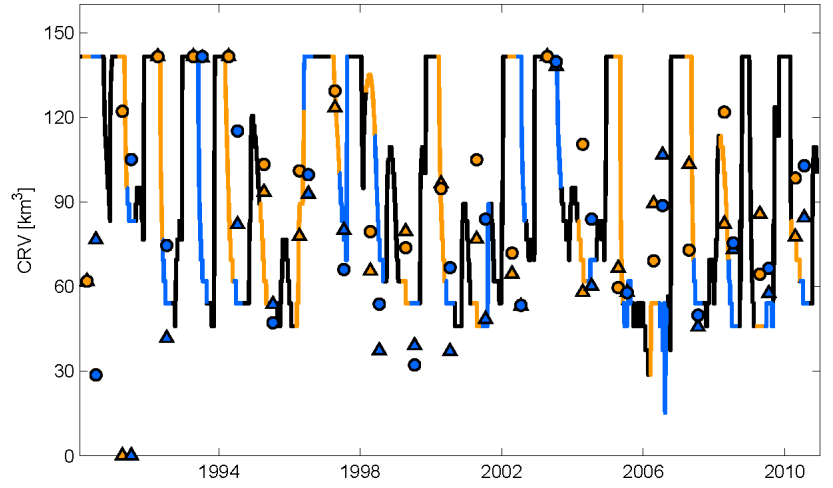

Figure 8. The modeled cod reproduction volume (CRV) (black line). The second and third quarter periods are highlighted by yellow and blue, respectively. The second and third quarterly average cod reproduction volumes, calculated from BY4 and BY5 data, are represented by triangles and circles, respectively.

ter, should be negligibly influenced by the pumping. However, since the oxygenation reduces the leakage of phosphorus into the deepwater of the Bornholm Basin (Stigebrandt et al., 2014a), this water will carry less phosphorus with it when it is flushed and further transported into the basins east of the Bornholm Basin. Consequently, there will be a decreased upwelling of $\mathrm{P}$ in the basins east of the Bornholm Basin. The effect of decreased P loading of the Baltic Proper will eventually also be felt in the surface layer of the Bornholm Basin, as an indirect effect of the pumping, and lead to a decreased production of organic matter sinking down into the deep basin. This will be beneficiary to cod recruitment, since the oxygen consumption decreases in the deepwater. The benthic biomass will get less feed falling down from the surface layers.

\subsection{The effect on cod reproduction volume by artificial mixing}

The CRV was calculated as the volume below $61 \mathrm{~m}$ depth that fulfills the definition in Sect. 2.2.2. These conditions may also be met above $61 \mathrm{~m}$ depth, but cod eggs present above this depth might be transported out from the Bornholm Basin by the outflow and, during that process, salinity will likely decrease due to entrainment. Therefore, the water volume above this depth is not included in the calculation of CRV. The total water volume below $61 \mathrm{~m}$ depth is $142 \mathrm{~km}^{3}$, which is thus the upper limit for the CRV in our approach.

The quarterly CRV from the model (no pumping) is compared to the CRV calculated from observations from BY4 and BY5 (Fig. 8). The second (April to June) and third (July to September) quarters are the periods when cod spawning occurs, and these periods are highlighted in Fig. 8. The minimum and average CRV given by the model are 16 and $88 \mathrm{~km}^{3}$, respectively. The corresponding values from observations were calculated to 0 and $78 \mathrm{~km}^{3}$ for BY4 and 29 and

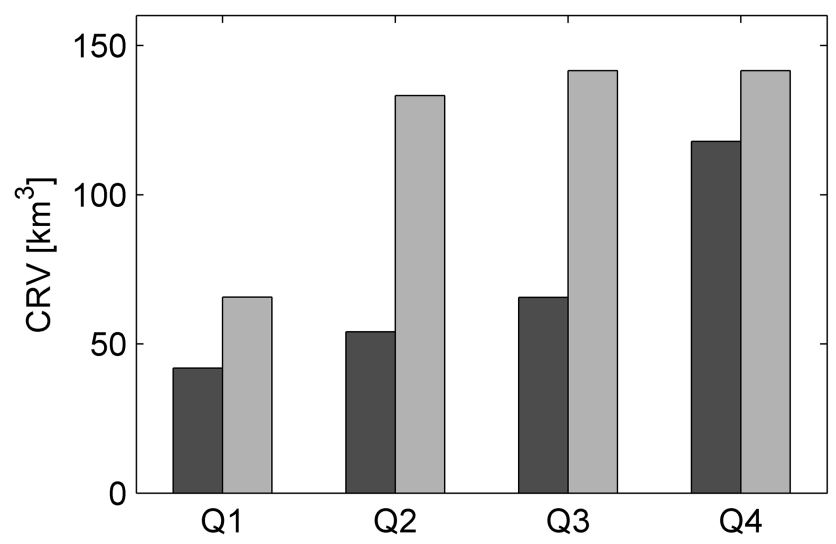

Figure 9. Model average cod reproduction volumes (CRV) from the second and third quarters of the year separated by quartiles and averaged, here presented in rising order (Q1-Q4). Dark grey bars represent the model reference run (no pump) and the light grey bars represent the model with a pump volume flow of $1000 \mathrm{~m}^{3} \mathrm{~s}^{-1}$.

$89 \mathrm{~km}^{3}$ for BY5. It is apparent from these values and from Fig. 8 that the modeled CRV generally follows the observed CRV well.

There are apparently observations during the studied period when the CRV is small and even vanishes (Fig. 8). We have partitioned the CRV data by quartiles, Q1-Q4, and calculated the average for each partition. The average of the lowest $25 \%$ of the CRV values (Q1) based on spring and summer model values equals approximately $40 \mathrm{~km}^{3}$ (Fig. 9). By pumping $1000 \mathrm{~m}^{3} \mathrm{~s}^{-1}$, this value would increase to more than $65 \mathrm{~km}^{3}$ (see also Table 2 for results of other tested pumping rates). Figure 9 shows that it is in particular during years with small CRVs that pumping might make a big difference. Thus, by pumping, there will be a large CRV each year, and cod recruitment should not fail in any single year due to lacking CRV.

The model runs with the pump intake at 0 and $40 \mathrm{~m}$ depth showed a similar variation as the runs in Table 2, but with a somewhat smaller CRV for the $40 \mathrm{~m}$ intake. For example, the Q1 and minimum CRV with a pump volume flow of $1000 \mathrm{~m}^{3} \mathrm{~s}^{-1}$ were 66 and $54 \mathrm{~km}^{3}$ for the $30 \mathrm{~m}$ intake depth. For an intake placed at $40 \mathrm{~m}$, these values were 60 and $46 \mathrm{~km}^{3}$. The corresponding values with the intake located at the sea surface are 70 and $54 \mathrm{~km}^{3}$.

Gustafsson et al. (2008) performed computations showing that halocline ventilation might not increase CRV. This is opposite to the conclusion reached in the present paper. The reason for the diverging opinions is that Gustafsson et al. (2008) reached their result without studying the conditions in the Bornholm Basin explicitly, the only basin with successful cod recruitment during the last decades.

The oxygenation of the deepwater in the Bornholm Basin may only marginally change the supply of organic matter and the oxygen consumption in the basin water beneath the sill 
depth, as explained above. The changes in hydrography and oxygen conditions induced by pumping will therefore be lost when the pumps are turned off for a longer period or permanently.

\subsection{Outflow of deepwater from the Bornholm Basin}

The effects of artificial mixing on the water flowing from the Bornholm Basin to the Stolpe Channel were investigated for the pumping rate of $1000 \mathrm{~m}^{3} \mathrm{~s}^{-1}$. The total geostrophic transport, reference flow ca. $30000 \mathrm{~m}^{3} \mathrm{~s}^{-1}$, increases by approximately $2 \%$. Transports with the highest salinities (ref. ca. $9000 \mathrm{~m}^{3} \mathrm{~s}^{-1} ; S>13$ ) decrease by $17 \%$. Flows with oxygen content less than $2 \mathrm{mLL}^{-1}$ disappear completely, while flows in general are shifted towards higher oxygen content. For instance, volume transports with very high oxygen content (ref. ca. $6300 \mathrm{~m}^{3} \mathrm{~s}^{-1} ; \mathrm{O}_{2}>7 \mathrm{mLL}^{-1}$ ) increase by $10 \%$. The model thus shows that the salinity distribution of the outflow to the Stolpe Channel becomes narrower and the oxygen concentration becomes higher when artificial mixing is applied. This should decrease the vertical stratification, as shown by a numerical experiment in Stigebrandt (1987b), and improve the oxygen conditions in the deeper parts of the Baltic Proper east of the Bornholm Basin.

\subsection{Benthic fauna, potential new biomass and fish feed}

The benthic fauna in the Bornholm Basin was studied in the 1950s and 1960s by Demel and Mulicki (1954) and Leppäkoski (1969), respectively, in relation to changes in salinity (13.5-17) and oxygen concentrations $\left(0-5 \mathrm{~mL} \mathrm{~L}^{-1}\right)$. Up to seven species were recorded in the area deeper than $70 \mathrm{~m}$, and in the 1950s, the bivalve Astarte borealis was the most common and had the highest biomass. Among potential colonizers in the deeper Bornholm Basin, should the oxygen be high over several years, are the bivalves Astarte borealis, Macoma balthica and Macoma calcarea; the polychaetes Halicryptus spinulosus, Scoloplos armiger, Capitella capitata and Harmothoe sarsi; and the crustaceans Diasylis rathkei, Pontoporeia affinis and Pontoporeia femorata. In the 1960s, bivalves were rare and, instead, polychaetes, particularly Scoloplos armiger, colonized the bottoms during periods of re-oxygenation. However, the oxygen could drop from 4-5 $\mathrm{mL} \mathrm{L}^{-1}$ to less than $1 \mathrm{~mL} \mathrm{~L}^{-1}$ during a few months.

The biomasses of the benthic fauna in the 1960s were much lower at depths greater than $70 \mathrm{~m}$ than in the 1950s, probably as a result of overly short periods of suitable oxygen conditions to let a healthy community establish itself. The average biomass at seven stations greater than $70 \mathrm{~m}$ in depth in the $1950 \mathrm{~s}$ was $17.5 \mathrm{~g} \mathrm{~m}^{-2}$ wet weight. Karlson et al. (2002) estimated that about 50000 ton of benthic biomass could be missing in the Bornholm Basin during hypoxic/anoxic conditions in the area. Should re-oxygenation of the Bornholm Basin also have positive secondary effects on the oxygen conditions in the Baltic Proper, an additional biomass on the order of 1400000 ton could be the result, as was estimated by Karlson et al. (2002).

The recruitment of benthic animals into pre-hypoxic areas with a low diversity may be facilitated by the fact that only a few niches are preoccupied and competition is low. Initially, the new recruits are likely to have a high production, and demersal fish such as cod could benefit from the new food source.

A local example of re-colonization of benthic fauna of formerly dead bottoms is from the rather enclosed inner Stockholm archipelago. After reducing the input of phosphorus from the sewage of the city, the oxygen concentrations in the deeper waters improved. In 1996 to 1998, all sediment samples at 20 to $50 \mathrm{~m}$ were black and reduced (Rosenberg and Diaz, 1993), but, in 2008, seven of these eight stations had an oxidized sediment surface (Karlsson et al., 2010). The authors recorded abundances of between 2300 and 5600 ind. $\mathrm{m}^{-2}$ and biomasses of between 6 and $65 \mathrm{~g} \mathrm{~m}^{-2}$ (wet weight, excluding the reduced station). The invasive polychaete Marenzelleria neglecta was totally dominant at all stations, and is a fast colonizer in great numbers. Marenzelleria spp. could possibly also colonize the deeper parts of the presently anoxic/hypoxic Bornholm Basin and the Baltic Proper if these areas were oxidized. Should this worm establish itself in the present defaunated area of ca. $80000 \mathrm{~km}^{2}$ in the Baltic Proper with biomasses of the same weights as in the Stockholm archipelago, the total biomass could be on the order of 0.5 to 5.0 million ton, i.e., on the same order as calculated above. As a comparison, Cederwall et al. (1999) found Marenzelleria viridis invading the Gulf of Riga in 1993 to 1996 in average biomasses of $11.8 \mathrm{~g} \mathrm{~m}^{-2}$. The species Marenzelleria spp. is described in more detail in Sect. 4.7.

\subsection{Bioturbation and related benthic biogeochemical processes}

Benthic faunal activities have a significant impact on biogeochemical processes in the sediment globally through bioturbation, i.e., reworking the sediment by digging and burrowing; oxygenation of burrows and voids; and biodeposition of particles on the sediment surface and into the water column. Different species have different activity patterns and, in general, larger and more active species have a larger impact on sediment and irrigation processes. As the number of species in the brackish Baltic Sea are reduced compared to in more saline areas, the number of functions are also comparatively lower. Based on if animals are mobile or sessile, and where and how they feed, the number of "functional groups" can be calculated (Pearson and Rosenberg, 1987). Based on such a scheme, the number of functional groups in the Skagerrak are above 20 but only 8 in the southern Baltic (Bonsdorff and Pearson, 1999). Species missing in the Baltic (until recently) were those that were digging deep and feeding within the sediment (sub-surface deposit feeders) and animals using 
tentacles as feeding appendages. Thus, commonly only the upper few centimeters were bioturbated in the Baltic compared to several tens of centimeters in oceanic waters.

The spionid polychaete Marenzelleria spp., a recent invasive species first recorded in 1985, is a deep burrowing worm with consequences for the biogeochemical processes. Marenzelleria spp. consists of three different species that look alike and are difficult to separate into species. These species are nowadays common from shallow to deep waters and often dominant in many oxygenated areas of the Baltic. Marenzelleria spp. are both surface and subsurface deposit feeders and burrow deep $(10-30 \mathrm{~cm})$ into the sediment. They can locally reach numbers as high as 30000 ind. $\mathrm{m}^{-2}$ (Zettler et al., 2002).

By their intrusion into the Baltic, Marenzelleria spp. have added a new dimension to the Baltic sedimentary system. This genus constructs galleries in the sediment down to more than $10 \mathrm{~cm}$ and adds new niches and complex functions to the ecosystem services. The three-species complex of Marenzelleria is spread from shallow waters down to deeper oxygenated bottoms from the southern Baltic up to the Bothnian Sea and the Gulf of Finland. The genera are dominant in many areas and occur, with great variations, frequently in numbers of between 500 and 5000 ind. $\mathrm{m}^{-2}$, but with a somewhat heterogeneous distribution. The Marenzelleria spp. are potential invaders of the deeper Baltic sediments if the oxygenated areas are extended. It can colonize new areas by settlement of pelagic larvae or by actively swimming or crawling adults (Norkko et al., 2011). However, to what extent they will colonize these presently defaunated areas, and in which densities, remains unknown. Nonetheless, this is most likely to happen and the new invaders will, in addition to other colonizers, have a significant impact on the fluxes of nutrient in the sediment through their activities in the deep galleries.

The pool of inorganic phosphate in the sediment in the Baltic is clearly related to the oxygen concentration in the bottom-near water; phosphorus is bound to the sediment during oxic conditions and released under anoxic conditions (e.g., Conley et al., 2009a; Stigebrandt, et al., 2014a). Thus, when animals are present in the sediment, their bioturbation and ventilation of the sediment will increase the amount of phosphorus bound in the sediment. When Marenzelleria spp. occur in high densities, they can, through their deep burrowing activity, have a significant impact on these biogeochemical cycles. Quintana et al. (2011) found that Marenzelleria viridis had two types of ventilation - a muscular pumping of water out of the burrow and a ciliar pumping of water into the burrow. Significant amounts of water percolate upwards to the sediment surface, which will also have a significant effect on the reduction of sulfate in the sediment (Kristensen et al., 2011). Norkko et al. (2011) demonstrated in a model that Marenzelleria spp. had a significant density-dependent impact on the phosphorus cycling in the Baltic, where increasingly more phosphorus is bound to the sediment when the density increases beyond 3000 ind. $\mathrm{m}^{-2}$. The great capacity of Marenzelleria-bioturbated sediments to store phosphorus was demonstrated by the fact that twice as much was bound annually to the present-day oxic sediments in the Stockholm archipelago as annually could be removed by the sewage treatment plants in Stockholm.

Another possibility is that changed redox conditions in the sediment and activity of Marenzelleria spp. could increase the flux of contaminants such as PCBs compared to if the sediment remains anoxic (Granberg et al., 2008). Hedman et al. (2008) showed that contaminants and cadmium could be either buried or remobilized in the sediment because of the activity of different infaunal species. The authors emphasized the importance of understanding the complex interactions between ecological and physiochemical processes when assessing the fate of contaminants in aquatic ecosystems. Thus, more research is needed before any general and firm conclusions could be made regarding the fate of contaminants and metals in the Baltic if the seabed is re-oxygenated. However, the By Fjord oxygenation experiment did not lead to increased leakage of toxic organic compounds or toxic metals from the sediments when these became oxidized (Stigebrandt et al., 2014b).

Oxygenation of the deepwater should tend to decrease the oxygen consumption through the coupling between primary production and decreased leakage of phosphorus from deep bottoms and the following decreased phosphorus content in the surface layers. As in eutrophic lakes, a substantial fraction of the oxygen consumption might be due to fluxes of reduced substances from the sediments (Müller et al., 2012), which is why the decrease in oxygen consumption initially might be less than expected. However, provided the eutrophication of the Baltic Proper does not increase, there is no reason to expect that oxygen consumption should increase when artificial oxygenation is turned on in the Bornholm Basin at the suggested pumping rate.

\section{Concluding remarks}

From simulations of the vertical circulation in the Bornholm Basin in the period 1990 to 2010, we have shown that the deep Bornholm Basin may be kept oxic by pumping down about $1000 \mathrm{~m}^{3} \mathrm{~s}^{-1}$ of water from around $30 \mathrm{~m}$ depth. The average oxygen concentration in the basin will then be $3.6 \mathrm{mLL}^{-1}$, and the minimum concentration is estimated to $1.3 \mathrm{mLL}^{-1}$, compared to 1.9 and $-2.4 \mathrm{mLL}^{-1}$ without pumping. The rate of water exchange at $90 \mathrm{~m}$ depth increases from 66 to $160 \mathrm{~km}^{3}$ year $^{-1}$. Like in the By Fjord experiment (Stigebrandt et al., 2014b), increased water exchange in the deepwater is the main reason for why the supply of oxygen increases. The average salinity of the basin decreases from 15.4 to 14.4 , while the average temperature of $8.1^{\circ} \mathrm{C}$ remains almost unchanged.

The small CRV in certain years, endangering the recruitment of cod, would increase with oxygenation. The av- 
erage of the smallest $25 \%$ of CRV should, by pumping $1000 \mathrm{~m}^{3} \mathrm{~s}^{-1}$, increase from about 40 to more than $65 \mathrm{~km}^{3}$. Thus, oxygenation by increased deepwater ventilation might be a powerful method to strengthen cod reproduction in the Baltic Sea in years when the CRV otherwise would be small and even vanishing.

Benthic biomass will be established by colonization of sea bottoms, which means a new food source for demersal fish like cod and flatfish. Re-oxygenation of the deeper basins in the Baltic will undoubtedly have a positive effect on the recruitment and food availability for cod, which would be beneficial for the fisheries in the long run. Today the total annual catches of cod are only on the order of 50000 tons, whereas the potential might be 400000 tons, as it was in the 1990s (MacKenzie et al., 2002).

Reduced leakage of phosphorus from the sea bed in the Bornholm Basin by about 7500 ton per year (Stigebrandt et al., 2014a) will reduce the phosphorus content in the surface layer and thereby contribute to decreasing the eutrophication of the Baltic Sea. It will also reduce the magnitude and spatial extent of toxic cyanobacteria blooms in summer, with large socioeconomic and economic benefits for tourism. The present investigation also indicates that an isolated effort in the Bornholm Basin might give rise to positive effects in the East Gotland Basin, because the deepwater of the Bornholm Basin, which is exported to the East Gotland Basin, would be of lower salinity and contain less phosphorus and more oxygen. This should have positive impacts for the functioning of the ecosystem of the Baltic Proper.

The increase in biological production since the 1950s is the main reason for present-day hypoxia and anoxia. Oxygenation of the Bornholm Basin can contribute to decreased biological production, but the primary goal is to improve the oxygen conditions in the deep part of the basin and thereby also make the deepest parts habitable. However, as long as the biological production is not reduced to the level of the 1950s, the oxygen conditions in the Bornholm Basin will return to present-time conditions if the pumping is shut off. A reduction in the large-scale eutrophication might possibly be achieved by restoration of the Baltic Proper, which would require simultaneous oxygenation of all anoxic bottoms in the Baltic Proper. This will be discussed in a forthcoming paper.

The present paper contributes an important part of an analysis of the possible consequences of artificial oxygenation of the deepwater in the Bornholm Basin. Since the consequences are suggested to be positive, artificial oxygenation by pumping is recommended to be undertaken in the Bornholm Basin. It would be positive for the deepest bottom fauna also to oxygenate the Arkona Basin, which only requires a smaller effort. A carefully constructed observational control program, like the one in the By Fjord experiment (Stigebrandt et al., 2014b), should be run to study the various ecological and biogeochemical effects of such an oxygenation.
Acknowledgements. This work was supported by the Swedish EPA through contract number NV 08/307 F-255-08 (the BOX project) and by the Swedish Agency for Marine and Water Management through contract number $\mathrm{HaV}$ dnr 2415-11 and by the BSAP fund through the Nordic Investment Bank (NIB) (the BOX-WIN project). Stockholm sea level data and hydrographic data from stations BY4, BY5 and Anholt E were obtained through the Swedish Meteorological and Hydrological Institute (SMHI). Data from the entrance area, the Arkona Basin and the Gdansk Deep have been retrieved through the Baltic Nest Institute DAS application, with the assistance of Miguel Rodriguez Medina at the Baltic Sea Centre of Stockholm University, and the number of hydrographic profiles available for this study was increased by permission to access data from the Landesamt f. Umwelt, Naturschutz und Geologie M-V (LUNG M-V) and the NMFRI (former Sea Fisheries Institute in Gdynia, Poland). Anders Omstedt at the University of Gothenburg (Department of Earth Sciences) kindly provided data of river runoff to the Baltic Sea. Suggestions from the referees helped to improve the paper.

Edited by: J. A. Johnson

\section{References}

Arneborg, L., Fiekas, V., Umlauf, L., and Burchard, H.: Gravity current dynamics and entrainment - a process study based on observations in the Arkona Basin, J. Phys. Oceanogr., 37, 2094-2113, 2007.

Bonsdorff, E. and Pearson, Y. H.: Variation in the sublittoral macrozoobenthos of the Baltic Sea along environmental gradients: A functional-group approach, Aust. J. Ecol., 24, 312-326, 1999.

Bonsdorff, E., Blomqvist, E. M., Mattila, J., and Norkko, A.: Coastal eutrophication: causes, consequences and perspectives in the archipelago area of the northern Baltic Sea, Estuar. Coast. Shelf Sci., 44, 63-72, 1997.

Breitburg, D. L.: Effects of hypoxia, and the balance between hypoxia and enrichment, on coastal fishes and fisheries, Estuaries, 25, 767-781, 2002.

Cederwall, H., Jermakovs, V., and Lagzdins, G.: Long-term changes in the soft-bottom macrofauna of the Gulf of Riga, ICES J. Mar. Sci., 56, 41-48, 1999.

Conley, D. J., Björck, S., Bonsdorff, E., Carstensen, J., Destouni, G., Gustafsson, B. G., Hietanen, S., Kortekaas, M., Kuosa, H., Meier, H. E. M., Müller-Karulis, B., Nordberg, K., Norkko, A., Nürnberg, G., Pitkänen, H., Rabalais, N. N., Rosenberg, R., Savchuk, O. P., Slomp, C. P., Voss, M., Wulff, F., and Zillén, L.: Hypoxiarelated processes in the Baltic Sea, Environ. Sci. Technol., 43, 3412-3420, doi:10.1021/es802762a, 2009a.

Conley, D. J., Bonsdorff, E., Carstensen, J., Destouni, G., Gustafsson, B. G., Hansson, L.-A., Rabalais, N. N., Voss, M., and Zillén, L.: Tackling hypoxia in the Baltic Sea: Is engineering a solution?, Environ. Sci. Technol., 43, 3407-3411, doi:10.1021/es8027633, 2009b.

Demel, K. and Mulicki, Z.: Quantitative investigations on the biological bottom productivity of the South Baltic (in Polish with English summary), Prace Morskiego Instytutu Rybackiego w Gdyni, 7, 75-126, 1954. 
Diaz, R. J. and Rosenberg, R.: Marine benthic hypoxia: a review of its ecological effects and behavioural responses of marine macrofauna, Oceanogr. Mar. Biol., 33, 245-303, 1995.

Diaz, R. J. and Rosenberg, R.: Spreading dead zones and consequences for marine ecosystems, Science, 321, 926-929, 2008.

Elmgren, R.: The eutrophication status of the Baltic Sea: Input of nitrogen and phosphorus, their availability for plant production, and some management implications, Baltic Sea Environ. Proc. Helsinki, 30, 12-31, 1989.

Elmgren, R.: Understanding human impact on the Baltic ecosystem: changing views in recent decades, AMBIO, 30, 222-231, 2001.

Granberg, M., Gunnarsson, J., Hedman, J., Rosenberg, R., and Jonsson, P.: Bioturbation-driven release of sediment-associated contaminants from Baltic Sea sediments mediated by the invading polychaete Marenzelleria neglecta, Environ. Sci. Technol., 42, 1058-1065, 2008.

Gustafsson, B. G., Meier, H. E. M., Savchuk, O. P., Eilola, K., Axell, L., and Almroth, E.: Simulation of some engineering measures aiming at reducing effects from eutrophication of the Baltic Sea, Earth Sciences Centre, University of Gothenburg, Earth Sciences Report Series, C82, ISSN 1400-383X, 59 pp., 2008.

Hedman, J. E., Bradshaw, C., Thorsson, M. H., Gilek, M., and Gunnarsson, J. S.: Fate of contaminants in Baltic Sea sediments: role of bioturbation and settling organic matter, Mar. Ecol. Prog. Ser., 356, 25-38, 2008.

Hinrichsen, H.-H., Voss, R., Wieland, K., Köster, F., Andersen, K. H., and Margonski, P.: Spatial and temporal heterogeneity of cod spawning environment in the Bornholm Basin, Baltic Sea, Mar. Ecol. Prog. Ser., 345, 245-254, doi:10.3354/meps06989, 2007.

Jonsson, P., Carman, R., and Wulff, F.: Laminated sediments in the Baltic - a tool for evaluating nutrient mass balances, AMBIO, 19, 152-158, 1990.

Karlson, K., Rosenberg, R., and Bonsdorff, E.: Temporal and spatial large-scale effects of eutrophication and oxygen deficiency on benthic fauna in Scandinavian and Baltic waters - a review, Oceanogr. Mar. Biol., 40, 427-489, 2002.

Karlsson, M., Jonsson, P. O., Lindgren, D., Malmaeus, J. M., and Stehn, A.: Indicators of recovery from hypoxia in the inner Stockholm archipelago, AMBIO, 39, 486-495 2010.

Kristensen, E., Hansen, T., Delefosse, M., Banta, G., and Quintana, C. O.: Contrasting effects of the polychaetes Marenzelleria viridis and Nereis diversicolor on benthic metabolism and solute transport in sandy coastal sediment, Mar. Ecol.-Prog. Ser., 425, 125-139, 2011.

Leppäkoski, E.: Transitory return of the benthic fauna of the Bornholm Basin, after extermination by oxygen insufficiency, Cah. Biol. Mar. ,10, 163-172 1969.

Levin, L. A.: Oxygen minimum zone benthos: adaptation and community response to hypoxia, Oceanogr. Mar. Biol., 41, 1-45, 2003.

Liljebladh, B. and Stigebrandt, A.: Observations of the deepwater flow into the Baltic Sea, J. Geophys. Res., 101, 8895-8911, 1996.

MacKenzie, B. R., Hinrichsen, H.-H., Plikshs, M., Wieland, K., and Zezera, A. S.: Quantifying environmental heterogeneity: habitat size necessary for successful development of cod Gadus morhua eggs in the Baltic Sea, Mar. Ecol.-Prog. Ser., 193, 143-156, 2000.

MacKenzie, B. R., Alheit, J., Conley, D. J., Holm, P., and Kinzie, C. C.: Ecological hypotheses for a historical reconstruction of upper trophic level biomass in the Baltic Sea and Skagerrak, Can. J. Fish. Aquat. Sci., 59, 173-190, 2002.

Matthäus, W. and Schinke, H.: Mean atmospheric circulation patterns associated with major Baltic inflows, Dtsch. Hydrogr. Z., 46, 321-339, 1994.

Müller, B., Bryant, L.D., Matzinger, A., and Wüest, A.: Hypolimnetic oxygen depletion in eutrophic lakes, Environ. Sci. Technol., 46, 9964-9971, 2012.

Norkko, J., Reed, D. C., Timmermann, K., Norkko, A., Gustafsson, B. G., Bonsdorff, E., Slomp, C. P., Carstensen, J., and Conley, D. J.: A welcome can of worms? Hypoxia mitigation by an invasive species, Glob. Change Biol., 18, 422-434, doi:10.1111/j.13652486.2011.02513.x, 2011.

Pearson, T. H. and Rosenberg, R.: Macrobenthic succession in relation to organic enrichment and pollution of the marine environment, Oceanogr. Mar. Biol., 16, 229-311, 1978.

Pearson, T. H. and Rosenberg, R.: Feast and famine: Structuring factors in marine benthic communities, in: 27th Symposium of the British Ecological Society Aberystwyth 1986, edited by: Gee, J .H. R. and Giller, P. S., Blackwell Scientific Publications, Oxford, 373-395, 1987.

Quintana, C. O., Hansen, T., Delefosse, M., Banta, G., and Kristensen, E.: Burrow ventilation and associated porewater irrigation by the polychaete Marenzelleria viridis, J. Exp. Mar. Biol. Ecol., 397, 179-187, 2011.

Rosenberg, R.: Benthic faunal dynamics during succession following pollution abatement in a Swedish estuary, Oikos, 27, 414427, 1976.

Rosenberg, R. and Diaz, R. J.: Sulfur bacteria (Beggiatoa spp.) mats indicate hypoxic conditions in the inner Stockholm Archipelago, AMBIO, 22, 32-36, 1993.

Rosenberg, R., Elmgren, R., Fleischer, S., Jonsson, P., Persson, G., and Dahlin, H.: Marine eutrophication case studies in Sweden, AMBIO, 19, 102-108, 1990.

Rosenberg, R., Agrenius, S., Hellman, B., Nilsson, H. C., and Norling, K.: Recovery of benthic habitats and fauna in a Swedish fjord following improved oxygen conditions, Mar. Ecol.-Prog. Ser., 234, 43-53, 2002.

Rutgersson, A., Omstedt, A., and Räisänen, J.: Net precipitation over the Baltic Sea during present and future climate conditions, Clim. Res., 22, 27-39, 2002.

Samuelsson, M. and Stigebrandt, A.: Main characteristics of the long-term sea level variability in the Baltic Sea, Tellus, 48A, 672-683, 1996.

Seifert, T., Tauber, F., and Kayser, B.: A high resolution spherical grid topography of the Baltic Sea - 2nd edition, Baltic Sea Science Congress, Stockholm, 25-29 November 2001, Poster \#147, available at: http://www.io-warnemuende. de/topography-of-the-baltic-sea.html (last access: 4 July 2014), 2001.

Stigebrandt, A.: A model for the exchange of water and salt between the Baltic and the Skagerrak, J. Phys. Ocean., 13, 411-427, 1983.

Stigebrandt, A.: Computations of the flow of dense water into the Baltic Sea from hydrographical measurements in the Arkona Basin, Tellus A, 39, 170-177 1987a.

Stigebrandt, A.: A model for the vertical circulation of the Baltic deep water, J. Phys. Oceanogr., 17, 1772-1785 1987b.

Stigebrandt, A.: Physical oceanography of the Baltic Sea, in: A systems analysis of the Baltic Sea, edited by: Wulff, F., Rahm, L., 
and Larsson, P., Springer-Verlag, Berlin, Heidelberg, New York, 19-74, 2001.

Stigebrandt, A. and Gustafsson, B.: Response of the Baltic Sea to climate change - theory and observations, J. Sea Res., 49, 243256, 2003.

Stigebrandt, A. and Gustafsson, B. G.: Improvement of Baltic proper water quality using large-scale ecological engineering, AMBIO, 36, 280-286, 2007.

Stigebrandt, A. and Kalén, O.: Improving oxygen conditions in the deeper parts of Bornholm Sea by pumped injection of winter water, AMBIO, 42, 587-595, doi:10.1007/s13280-012-0356-4, 2013.

Stigebrandt, A., Rahm, L., Viktorsson, L., Ödalen, M., Hall, P. O. J., and Liljebladh, B.: A new phosphorus paradigm for the Baltic proper, AMBIO, 43, 634-643, doi:10.1007/s13280-013-0441-3, 2014a.
Stigebrandt, A., Liljebladh, B., De Brabandere, L. Forth, M., Ganmo, Å., Hall, P. O. J., Hammar, J., Hansson, D., Kononets, M., Magnusson, M., Norén, F., Rahm, L., Treusch, A., and Viktorsson, L.: An experiment with forced oxygenation of the deepwater of the anoxic By Fjord, western Sweden, AMBIO, doi:10.1007/s13280-014-0524-9, 2014b.

Vallin, L., Nissling, A., and Westin, L.: Potential factors influencing reproductive success of Baltic cod, Gadus morhua: a review, AMBIO, 28, 92-99, 1999.

Zettler, M. L., Daunys, D., Kotta, J., and Bick, A.: History and success of an invasion into the Baltic Sea: the polychaete Marenzelleria $\mathrm{cf}$. viridis, development and strategies, in: Invasive aquatic species of Europe: distribution, impacts and management, edited by: Leppäkoski, E., Gollasch, S., and Olenin, S., Kluwer Academic Publishers, Dordrecht, 66-76, 2002. 